\title{
Sleep and Wakefulness Are Controlled by Ventral Medial Midbrain/Pons GABAergic Neurons in Mice
}

\author{
Yohko Takata, Yo Oishi, Xu-Zhao Zhou, Emi Hasegawa, Koji Takahashi, Yoan Cherasse, Takeshi Sakurai, \\ and $\odot$ Michael Lazarus \\ International Institute for Integrative Sleep Medicine (WPI-IIIS), University of Tsukuba, Tsukuba, Ibaraki 305-8575, Japan
}

\begin{abstract}
Sleep-wake behavior is controlled by a wide range of neuronal populations in the mammalian brain. Although the ventral midbrain/pons (VMP) area is suggested to participate in sleep-wake regulation, the neuronal mechanisms have remained unclear. Here, we found that nonspecific cell ablation or selective ablation of GABAergic neurons by expressing diphtheria toxin fragment A in the VMP in male mice induced a large increase in wakefulness that lasted at least 4 weeks. In contrast, selective ablation of dopaminergic neurons in the VMP had little effect on wakefulness. Chemogenetic inhibition of VMP GABAergic neurons also markedly increased wakefulness. The wakepromoting effect of the VMP GABAergic neuron ablation or inhibition was attenuated to varying degrees by the administration of dopamine D1 or D2/3 receptor antagonists and abolished by the administration of both antagonists together. In contrast, chemogenetic activation of VMP GABAergic neurons very strongly increased slow-wave sleep and reduced wakefulness. These findings suggest that VMP GABAergic neurons regulate dopaminergic actions in the sleep-wake behavior of mice.
\end{abstract}

Key words: AAV; arousal; DREADD; EEG; neural circuits; REM sleep

\section{Significance Statement}

Current understanding of the neuronal mechanisms and populations that regulate sleep-wake behavior is incomplete. Here, we identified a GABAergic ventral midbrain/pons area that is necessary for controlling the daily amount of sleep and wakefulness in mice. We also found that these inhibitory neurons control wakefulness by suppressing dopaminergic systems. Surprisingly, activation of these neurons strongly induced slow-wave sleep while suppressing wakefulness. Our study reveals a new brain mechanism critical for sleep-wake regulation.

\section{Introduction}

One potential function of sleep is to conserve energy by enforcing inactivity when activity is not beneficial (Siegel, 2009). Conversely, when varying ecological demands favor wakefulness, animals may have the ability to dispense with sleep. The circuit mechanisms underlying the control of wakefulness to adapt an

Received March 4, 2018; revised Sept. 20, 2018; accepted Sept. 24, 2018.

Author contributions: Y.O. and M.L. designed research; Y.T., X.-Z.Z., E.H., and K.T. performed research; Y.C. contributed unpublished reagents/analytic tools; Y.T., Y.O., X.-Z.Z., E.H., and T.S. analyzed data; Y.T., Y.O., E.H., and M.L. wrote the paper.

This work was supported by the Japan Society for the Promotion of Science [Grant-in-Aid for Young Scientists (B) JP15K18359 and Grant-in-Aid for Scientific Research (B) JP18H02534 to Y.0. and Grant-in-Aid for Scientific Research (B) JP17H02215 to M.L.]; the Japan Science and Technology Agency (CREST Grant JPMJCR1655 to M.L.); the Ministry of Education, Culture, Sports, Science, and Technology (MEXT) of Japan (Grants-in-Aid for Scientific Research on Innovative Areas "Living in Space" JP15H05935, JP15K21745, JP18H04966, and "Willdynamics" JP17H06047 to M.L.); the World Premier International Research Center Initiative from MEXT (Y.T., Y.O., Y.C., and M.L.); the Japan Foundation for Applied Enzymology (Y.O.); and the Naito Foundation (M.L.).

The authors declare no competing financial interests.

Correspondence should be addressed to either Michael Lazarus or Yo Oishi, International Institute for Integrative Sleep Medicine (WPI-IIIS), University of Tsukuba, 1-1-1 Tennodai, Tsukuba, Ibaraki 305-8575, Japan, E-mail: lazarus.michael.ka@u.tsukuba.ac.jp or oishi.yo.fu@u.tsukuba.ac.jp.

https://doi.org/10.1523/JNEUROSCI.0598-18.2018

Copyright $\odot 2018$ the authors $\quad 0270-6474 / 18 / 3810080-13 \$ 15.00 / 0$ animal's amount of sleep to its behavior, however, are largely unknown.

We recently identified indirect pathway neurons in the nucleus accumbens as sleep-controlling neurons (Oishi et al., $2017 b)$. The nucleus accumbens is innervated by ventral tegmental area (VTA) neurons in the ventral portion of the midbrain (Taylor et al., 2014; Oishi and Lazarus, 2017). Although we and others have reported that activation of the VTA dopaminergic neurons strongly induces wakefulness (Eban-Rothschild et al., 2016; Taylor et al., 2016; Oishi et al., 2017a), the role of this midbrain area in sleep-wake regulation remains unclear because the findings are conflicting. In rats, neurotoxic lesions of the cells in this area with hypocretin-2-saporin have no effect on sleepwake behavior (Gerashchenko et al., 2006). In cats, electrolytic lesions of the ventral midbrain area, including the VTA, has no significant effect on sleep-wake behavior (Jones et al., 1973), whereas $N$-methyl-D-aspartate lesions of cells in an area containing the VTA produce insomnia (Lai et al., 1999).

In the present study, we used an ablation technique based on the viral expression of diphtheria toxin fragment A (DTA) and found that nonspecific or GABAergic neuron-specific ablations 
in the ventral medial midbrain/pons area (VMP) at the junction of the ventral medial midbrain and pons largely increased wakefulness in mice. The increased wakefulness was also observed after chemogenetic inhibition of the VMP GABAergic neurons. Using pharmacologic tools, we further demonstrated that this arousal effect was mediated by dopaminergic systems. These findings indicate that the VMP GABAergic cells are critical for the control of sleep-wake behavior.

\section{Materials and Methods}

Mice and chemicals. We used the following mouse lines: C57BL/6J wildtype (WT, Charles River Laboratories), dopamine transporter (DAT)Cre (Bäckman et al., 2006) (The Jackson Laboratory 006660), and vesicular GABA transporter (VGAT)-Cre (Vong et al., 2011) (kindly provided by Dr. Bradford Lowell, Harvard Medical School). Male mice (8-20 weeks, $25-35 \mathrm{~g})$ were used for the behavioral studies and housed in insulated sound-proof recording chambers maintained at an ambient temperature of $23 \pm 0.5^{\circ} \mathrm{C}$ with $55 \pm 3 \%$ humidity on a $12 \mathrm{~h} \mathrm{light/dark}$ cycle (lights on at 8:00) and provided food and water ad libitum. All experiments were performed in accordance with the Animal Care Committee of the University of Tsukuba and every effort was made to minimize the number of animals used as well as any pain or discomfort.

Clozapine- $\mathrm{N}$-oxide (CNO, Millipore-Sigma), the selective D1 receptor antagonist SCH23390 (Millipore-Sigma), the selective D2/D3 receptor antagonist raclopride (Millipore-Sigma), and histamine $\mathrm{H} 1$ receptor antagonist ketotifen (Tokyo Chemical) were dissolved in saline.

Plasmids and adeno-associated viral vectors (AAVs). To generate the pAAV-CMV-FLEX-DTA plasmid, a FLEX-DTA cassette (see Fig. 1A) was synthesized by Eurofins Genomics K.K. and inserted between the $\mathrm{ClaI}$ and BamHI restriction sites in a pAAV-MCS vector (Stratagene). To generate the pAAV-CMV-FLEX-hrGFP plasmid, the DTA fragment between the AscI and NheI restriction sites in pAAV-CMV-FLEX-DTA was replaced with the hrGFP coding sequence. The plasmids pAAV-hSynFLEX-hM4Di-mCherry and pAAV-hSyn-FLEX-hM3Dq-mCherry (Krashes et al., 2011) were kindly provided by Dr. Bryan Roth (University of North Carolina School of Medicine, Chapel Hill, NC). The plasmids generated in this study will be deposited in Addgene.

pAAV-CMV-FLEX-DTA, pAAV-CMV-FLEX-hrGFP, pAAV-CMVCre (Lazarus et al., 2011), pAAV-hSyn-FLEX-hM4Di-mCherry, or pAAV-hSyn-FLEX-hM3Dq-mCherry were packaged in the AAV of serotype rh10 using 293A cells as described previously (Kaur et al., 2017; Oishi et al., 2017a,b).

Surgery. For brain microinjections, mice anesthetized with pentobarbital $\left(60 \mathrm{mg} \mathrm{kg}^{-1}\right.$, i.p.) were injected bilaterally into the VMP (3.4 mm posterior and $0.2 \mathrm{~mm}$ lateral to bregma, $4.4 \mathrm{~mm}$ below the dura) with 60 $\mathrm{nl}$ per injection of AAV using a glass micropipette and an air pressure injector system. To generate mice with nonselective cell-type ablation, WT mice were injected with a mixture (1:1) of AAV-FLEX-DTA $(8.6 \times$ $10^{10}$ particles $\left.\mathrm{ml}^{-1}\right)$ and AAV-Cre $\left(1.5 \times 10^{11}\right.$ particles $\left.\mathrm{ml}^{-1}\right)$ or AAVFLEX-DTA alone. To generate mice with dopaminergic or GABAergic neuron ablation, DAT-Cre mice or VGAT-Cre mice, respectively, were injected with AAV-FLEX-DTA or AAV-FLEX-hrGFP $\left(1.5 \times 10^{11}\right.$ particles $\mathrm{ml}^{-1}$ ). For the chemogenetic experiments, the VGAT-Cre mice were injected with AAV-FLEX-hM4Di-mCherry $\left(1.1 \times 10^{11}\right.$ particles $\left.\mathrm{ml}^{-1}\right)$ or AAV-FLEX-hM3Dq-mCherry $\left(1.1 \times 10^{11}\right.$ particles $\left.\mathrm{ml}^{-1}\right)$.

Mice were also chronically implanted with electroencephalography (EEG) and electromyography (EMG) electrodes for polysomnography, as described previously (Oishi et al., 2016). Briefly, the implant comprised two stainless steel screws serving as EEG electrodes and two insulated, Teflon-coated silver wires were placed bilaterally into the trapezius muscles to serve as EMG electrodes. The electrodes were fixed to the skull with dental acrylic.

EEG/EMG recordings. After allowing 1-2 weeks for postoperative recovery and transgene expression, the mice were connected with EEG/ EMG recording cables. The EEG/EMG signals were amplified and filtered (EEG: $0.5-64 \mathrm{~Hz}$, EMG: $16-64 \mathrm{~Hz}$ ), digitized at a sampling rate of $128 \mathrm{~Hz}$, and recorded using SLEEPSIGN software (Kissei Comtec). Vigilance states were scored offline by characterizing $10 \mathrm{~s}$ epochs into three stages: (1) awake, (2) slow-wave sleep (SWS), and (3) rapid eye movement sleep (REMS) according to standard criteria (Oishi et al., 2016).

Pharmacologic and chemogenetic experiments. After baseline recordings for $24 \mathrm{~h}$, VGAT-Cre ${ }^{\text {DTA/VMP }}$ mice were administered saline, $0.03 \mathrm{mg}$ $\mathrm{kg}^{-1} \mathrm{SCH} 23390,2 \mathrm{mg} \mathrm{kg}^{-1}$ raclopride, or $10 \mathrm{mg} \mathrm{kg}^{-1}$ ketotifen at 10:00. Each mouse received all combinations of dopamine receptor antagonists in a random order with at least $3 \mathrm{~d}$ intervals between drug administrations. A separate mouse group received ketotifen. Doses of the drugs were selected based on previous studies (Qu et al., 2008; Unno et al., 2012; Oishi et al., 2017a). For chemogenetic inhibition, VGAT-Cre M4/VMP $^{-1}$ mice were injected intraperitoneally with saline or $3 \mathrm{mg} \mathrm{kg}^{-1} \mathrm{CNO}$ at 10:00 on 2 consecutive days. For chemogenetic activation, each VGAT$\mathrm{Cre}^{\mathrm{M} 3 / \mathrm{VMP}}$ mouse received intraperitoneally saline or different doses $\left(0.3,0.9\right.$, and $\left.2.7 \mathrm{mg} \mathrm{kg}^{-1}\right)$ of $\mathrm{CNO}$ at 20:00 with at least $3 \mathrm{~d}$ intervals between drug administrations.

Histology. Under deep anesthesia with an overdose of chloral hydrate (500 $\mathrm{mg} \mathrm{kg}^{-1}$, i.p.), animals were perfused intracardially with saline followed by neutral buffered $10 \%$ formalin. Brains were then placed in $20 \%$ sucrose overnight at $4^{\circ} \mathrm{C}$ to reduce freezing artifact. The brains were sectioned at $40 \mu \mathrm{m}$ on a freezing microtome.

For immunohistochemistry, sections were incubated in $0.3 \%$ hydrogen peroxide and then overnight with rabbit anti-DsRed (1:10,000, Clontech, catalog \#632496, RRID:AB_10013483), mouse anti-NeuN (1:2000, Millipore, catalog \#MAB377, RRID:AB_2298772), or rabbit antityrosine hydroxylase (TH; 1:20,000, Millipore, catalog \#AB152, RRID: AB_390204). Sections were incubated for $2 \mathrm{~h}$ in biotinylated antibody (1:1000, Jackson ImmunoResearch Laboratories) and treated with avidin-biotin complex (1:1000; Vectastain ABC Elite kit, Vector Laboratories) for $1 \mathrm{~h}$. Immunoreactive cells were visualized by reaction with $3,3^{\prime}$-diaminobenzidine and $0.01 \%$ hydrogen peroxide.

For in situ hybridization, we generated a 918-bp digoxigenin-labeled riboprobe for VGAT mRNA by PCR amplification (primers: forward, gcatgttcgtgctgggcctacc; reverse, cagcgcagcgtcagcccccag conjugated with the T7 promoter) using mouse tail genomic DNA as a template, followed by in vitro transcription. Sections were then incubated with a $1 \mu \mathrm{g} \mathrm{ml}^{-1}$ concentration of the VGAT probe in $5 \times$ sodium citrate buffer containing $50 \%$ formamide at $50^{\circ} \mathrm{C}$ overnight, washed in $1 \times$ saline sodium citrate buffer at $50^{\circ} \mathrm{C}$, incubated with alkaline phosphatase conjugated antidigoxigenin antibody (1:500, Roche) overnight, and visualized by reaction with 5-bromo-4-chloro-3-indolyl phosphate/nitro blue tetrazolium (BCIP/NBT, Millipore-Sigma).

For double-labeling of c-Fos and mCherry, we immunostained c-Fos with rabbit anti-c-Fos antibody (1:2000, Millipore, catalog \#ABE457, RRID:AB_2631318), peroxidase-conjugated anti-rabbit antibody (1: 250, Jackson ImmunoResearch Laboratories), and tyramide-conjugated fluorescein (PerkinElmer). mCherry-positive cells were identified by the native red fluorescence of mCherry. Images were analyzed with a confocal laser scanning microscope LSM800 (Carl Zeiss).

For quantitative histologic analysis, we counted cells positive for $\mathrm{TH}$, VGAT mRNA, c-Fos, or mCherry using a counting box placed bilaterally in the VMP. We placed a $500 \times 650 \mu \mathrm{m}$ box with the ventral medial edge at the center of the interpeduncular nucleus and the medial border along the midline $3.8 \mathrm{~mm}$ posterior to bregma. The anterior-posterior coordinates were obtained from the Paxinos and Franklin mouse brain atlas (Paxinos and Franklin, 2001). The cell counts were adjusted using the Abercrombie correction factor (Guillery, 2002).

Electrophysiology. Five-week-old VGAT-Cre mice were injected in the VMP with AAV-FLEX-hM4Di-mCherry or AAV-FLEX-hM3DqmCherry. After 1-2 weeks, the mice were decapitated under deep anesthesia with isoflurane (Pfizer). Brains were extracted and cooled in ice-cold cutting solution containing the following (in $\mathrm{mM}$ ): 125 choline chloride, $25 \mathrm{NaHCO}_{3}, 10 \mathrm{D}(+)$-glucose, $7 \mathrm{MgCl}_{2}, 2.5 \mathrm{KCl}, 1.25$ $\mathrm{NaH}_{2} \mathrm{PO}_{4}$, and $0.5 \mathrm{CaCl}_{2}$ bubbled with $\mathrm{O}_{2}(95 \%)$ and $\mathrm{CO}_{2}(5 \%)$. Horizontal brain slices $(250 \mu \mathrm{m}$ thick) including the VMP were prepared with a vibratome (VT1200S, Leica) and maintained for $1 \mathrm{~h}$ at room temperature in artificial CSF (ACSF) containing the following (in mM): $125 \mathrm{NaCl}$, $26 \mathrm{NaHCO}_{3}, 10 \mathrm{D}(+)$-glucose, $2.5 \mathrm{KCl}, 2 \mathrm{CaCl}_{2}$, and $1 \mathrm{MgSO}_{4}$ bubbled with $\mathrm{O}_{2}(95 \%)$ and $\mathrm{CO}_{2}(5 \%)$. The electrodes (5-8 $\mathrm{M} \Omega$ ) were filled with 
A
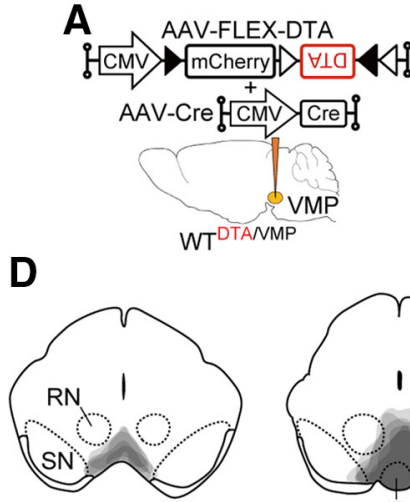

AP $-3.2 \mathrm{~mm}$
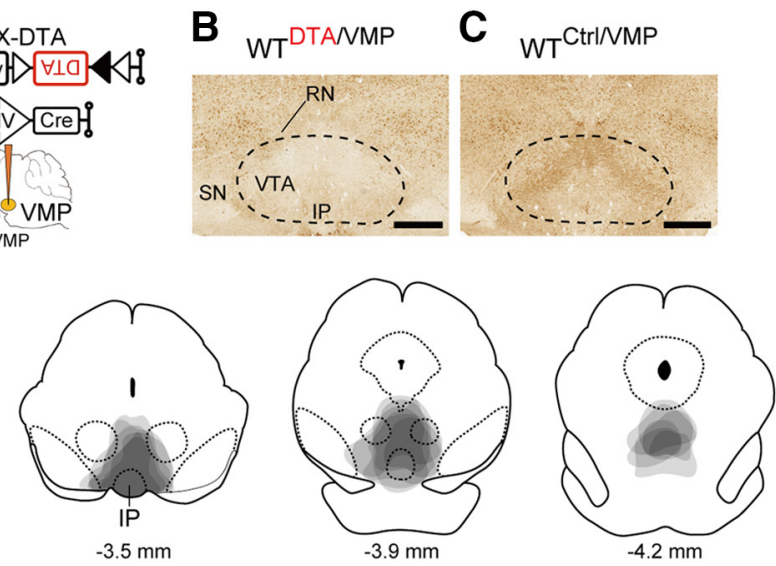

$$
\rightarrow-\square W T^{C t r / N M P} \rightarrow W^{\text {DTANMPP }}
$$

Wakefulness SWS
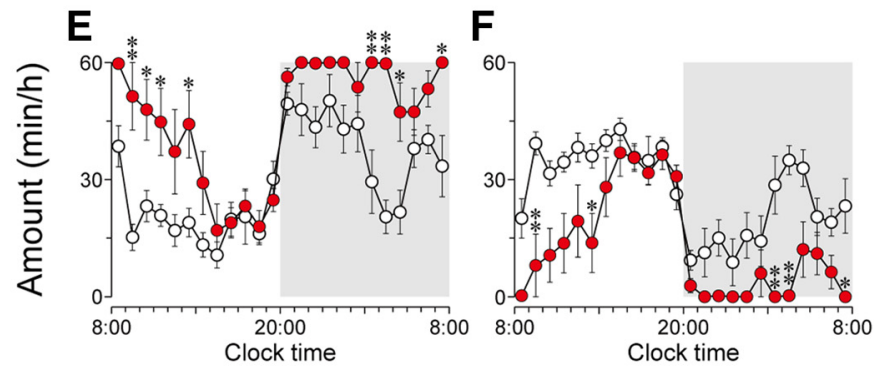

I
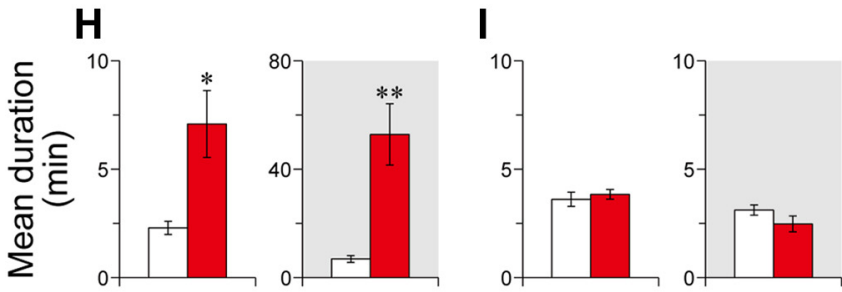

G

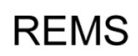

$\mathrm{K}$
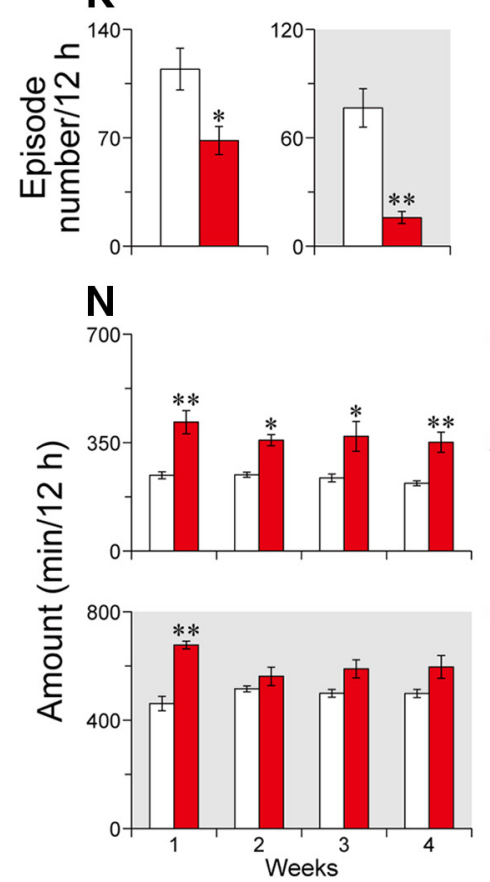

L

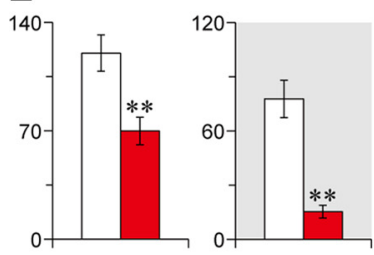

0
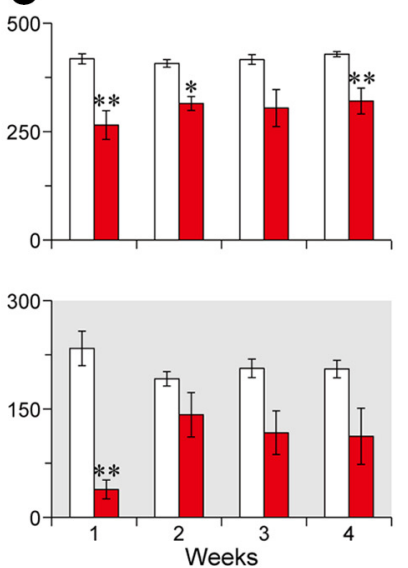

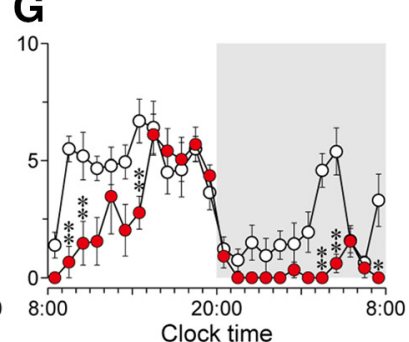

$\mathbf{J}$

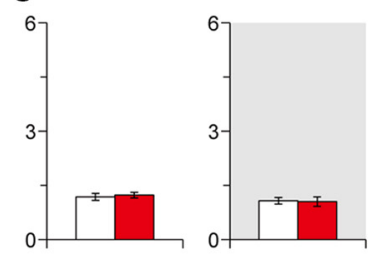

M

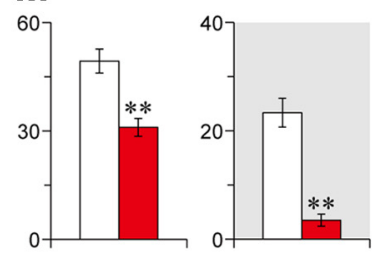

$\mathbf{P}$
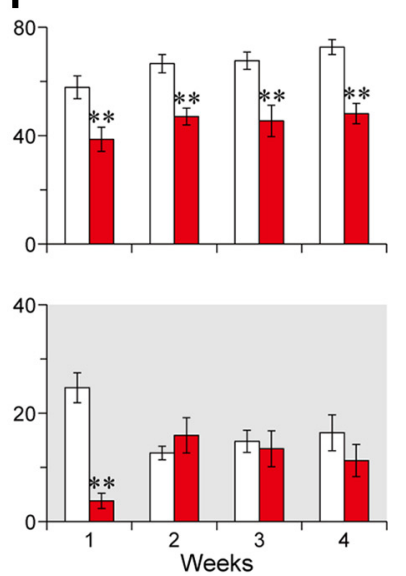

Figure 1. Ablation of the VMP increases wakefulness. $A$, WT mice were injected with AAV-FLEX-DTA and AAV-Cre into the VMP. $\boldsymbol{B}, \boldsymbol{C}$, Brain sections were stained against NeuN to confirm that the VMP neurons were ablated in the mice injected with AAV-FLEX-DTA and AAV-Cre (WT ${ }^{\text {DTA/VMP }}$ mice; $\boldsymbol{B}$ ). No deficiency in VMP neurons was detected in mice injected with only AAV-FLEX-DTA (WT ${ }^{\text {Ctr/VMP }}$ mice; $\boldsymbol{C}$. Dashed line delineates the area with neuronal loss in a WT ${ }^{\text {DTA/VMP }}$ mouse. Scale bar, $500 \mu$ m. $\boldsymbol{D}$, Superimposed neuronal loss areas in the (Figure legend continues.) 
an internal solution containing the following (in mM): $125 \mathrm{~K}$-gluconate, 10 HEPES, 10 phosphocreatine, $4 \mathrm{NaCl}, 4 \mathrm{ATP}, 2 \mathrm{MgCl}_{2}, 0.4 \mathrm{GTP}$, and 0.2 EGTA, pH 7.3, adjusted with $\mathrm{KOH})$. Firing of hM4Di-mCherry or hM3Dq-mCherry-expressing neurons was recorded in the currentclamp mode at a temperature of $30^{\circ} \mathrm{C}$, which was maintained by perfusion of preheated ACSF before and after $5 \mu \mathrm{M}$ CNO application. The combination of a MultiClamp 700B amplifier, a Digidata 1440A A/D converter, and Clampex 10.3 software (Molecular Devices) was used to control membrane voltage and data acquisition.

Experimental design and statistical analysis. For behavioral experiments, the numbers of mice used were chosen based on expected variations between animals and variability of AAV microinjections.

Data are presented as the mean and SEM. Statistical analyses were performed using GraphPad Prism software. Statistical comparisons between two groups were performed using the unpaired (see Figs. $1 H-M$; $2 F, J-O ; 3 F, J, K, M-O$, and $8 C, D$ ) or paired (see Figs. $4 C, D ; 5 D, F-H$, and $7 C)$ two-tailed Student's $t$ test. For $t$ tests, the normality of each dataset was established using the Kolmogorov-Smirnov test. Comparisons among multiple parameters were performed by a mixed-model ANOVA followed by Sidak's post hoc comparisons (see Figs. $1 E-G, N-P ; 2 G-$ $I, P-R$, and $3 G-I, P-S$ ), one-way repeated-measures ANOVA followed by Tukey's post hoc comparisons (see Figs. $4 A, B$ and $7 G-O$ ), or two-way repeated-measures ANOVA followed by Sidak's post hoc comparisons (Figs. $5 E, I ; 6 A-E$, and $7 D-F, P, Q$ ). In all cases, $p<0.05$ was considered significant.

\section{Results}

\section{VMP cell deficiency increases wakefulness in mice}

To examine the role of ventral midbrain neurons in sleep-wake regulation, we first nonselectively ablated cells in this brain area in WT mice by stereotaxic co-microinjection of AAV carrying Cre-dependent DTA (AAV-FLEX-DTA) and Cre recombinase (AAV-Cre; WT ${ }^{\mathrm{DTA} / \mathrm{VMP}}$ mice; Fig. $1 A, B$ ). Because the ablation was observed not only in the ventral medial portion of the midbrain, but also in a part of the pons as confirmed by immunostaining for the neuronal marker NeuN (Fig. $1 B-D$ ), the ablated area is hereafter referred to as the VMP. In all cases, the ablated area largely included the VTA and almost none of the substantia nigra. Control mice were only injected with AAV-FLEX-DTA into the VMP and did not express DTA in the VMP due to the absence of Cre recombinase (WT ${ }^{\mathrm{Ctrl} / \mathrm{VMP}}$ mice; Fig. $1 C$ ). At 1 week after the AAV injections, EEG and EMG recordings of the mice were analyzed to assess the baseline sleep-wake behavior of the animals. Compared with WT ${ }^{\mathrm{Ctrl} / \mathrm{VMP}}$ mice, $\mathrm{WT}^{\mathrm{DTA} / \mathrm{VMP}}$ mice exhibited largely increased wakefulness, especially in the first half of the light period, when mice typically show high levels of sleep, but also in the second half of the dark period $\left(F_{(1,10)}=66.7, p<\right.$ 0.0001, ANOVA; Fig. $1 E$ ). Concomitantly, WT ${ }^{\text {DTA/NMP }}$ mice had a lower amount of SWS $\left(F_{(1,10)}=60.9, p<0.0001\right.$, ANOVA; Fig. $1 F)$ and REMS $\left(F_{(1,10)}=73.4, p<0.0001\right.$, ANOVA; Fig. $\left.1 G\right)$. We then examined the pattern of waking in $\mathrm{WT}^{\mathrm{DTA} / \mathrm{VMP}}$ and $\mathrm{WT}^{\mathrm{Ctr} / \mathrm{VMP}}$ mice. The mean duration of wake episodes in the $\mathrm{WT}^{\mathrm{DTA} / \mathrm{VMP}}$ mice was $3.1\left(t_{(10)}=3.05, p=0.012\right.$, unpaired $t$ test; light period) and $7.7\left(t_{(10)}=4.03, p=0.0024\right.$, unpaired $t$ test; dark period $)$ times longer than that of wake episodes in the $\mathrm{WT}^{\mathrm{Ctrl} / \mathrm{VMP}}$ mice

(Figure legend continued.) VMP $(n=6)$. $\boldsymbol{E}-\boldsymbol{G}$, Time course of hourly wakefulness $(\boldsymbol{E})$, SWS $(\boldsymbol{F})$, and REMS $(\boldsymbol{G})$ at 1 week after surgery. $\boldsymbol{H}-\boldsymbol{M}$, Ablation of the VMP resulted in a longer mean duration of wake episodes $(\boldsymbol{H}-\boldsymbol{J})$, whereas the mean number of each episode was smaller $(\boldsymbol{K}-\boldsymbol{M}) . \boldsymbol{N}-\boldsymbol{P}$, Ablation of the VMP resulted in higher amounts of wakefulness $(\boldsymbol{N})$ and lower amounts of SWS $(\boldsymbol{O})$ and REMS $(\boldsymbol{P})$ for at least 4 weeks after surgery. White and gray background in each panel indicate light and dark periods, respectively. ${ }^{*} p<0.05,{ }^{* *} p<0.01$ compared with $\mathrm{WT}^{\mathrm{Ctrl} / \mathrm{NMP}}$ mice. Data are presented as the mean \pm SEM $(n=6)$. RN, Red nucleus; SN, substantia nigra; IP, interpeduncular nucleus.
(Fig. $1 H$ ), whereas the number of wake episodes was lower by $37 \%\left(t_{(10)}=2.85, p=0.0172\right.$, unpaired $t$ test $)$ and $85 \%\left(t_{(10)}=\right.$ 5.44, $p=0.0003$, unpaired $t$ test) in the light and dark periods, respectively (Fig. $1 K$ ), suggesting that ablation of VMP cells efficiently consolidates wakefulness. The mean duration of SWS and REMS was unchanged (light period SWS: $t_{(10)}=0.57, p=0.58$; dark period SWS: $t_{(10)}=1.46, p=0.17$; light period REMS: $t_{(10)}=0.38, p=0.71$; dark period REMS: $t_{(9)}=0.14, p=0.89$, unpaired $t$ test; Fig. $1 I, J)$, whereas the episode number was decreased in $\mathrm{WT}^{\mathrm{DTA} / \mathrm{VMP}}$ mice (light period SWS: $t_{(10)}=3.42, p=$ 0.0066; dark period SWS: $t_{(10)}=5.71, p=0.0002$; light period REMS: $t_{(10)}=4.42, p=0.0013$; dark period REMS: $t_{(10)}=6.89$, $p<0.0001$, unpaired $t$ test; Fig. $1 L, M)$. Animals have the ability to adapt their sleep-wake behavior after the loss of brain cells over the course of several weeks (Lai et al., 1999; Gerashchenko et al., 2006), so we measured EEG activity for up to 4 weeks after surgery. Although the wake amount of $\mathrm{WT}^{\mathrm{DTA} / \mathrm{VMP}}$ mice in the dark period reached the same level as that of the $\mathrm{WT}^{\mathrm{Ctrl} / \mathrm{VMP}}$ mice between 2 and 4 weeks after surgery, the $\mathrm{WT}^{\text {DTA/VMP }}$ mice maintained significantly higher amounts of wakefulness in the light period, even at 4 weeks after surgery (light period: $F_{(1,10)}=21.4$, $p=0.0009$; dark period: $F_{(1,10)}=15.5, p=0.0028$, ANOVA; Fig. $1 N)$. SWS and REMS amount were concomitantly lower in $\mathrm{WT}^{\text {DTA/VMP }}$ mice especially during the light period (light period SWS: $F_{(1,10)}=18.1, p=0.0017$; dark period SWS: $F_{(1,10)}=16.2$, $p=0.0024$; light period REMS: $F_{(1,10)}=26.0, p=0.0005$; dark period REMS: $F_{(1,10)}=6.50, p=0.0289$, ANOVA; Fig. $\left.1 O, P\right)$. These findings suggest that VMP cells contribute to the sleepwake behavior of mice and that the absence of these cells cannot be compensated for by other brain areas, at least in the light period.

\section{VMP dopaminergic neuron deficiency has little to no effect on wakefulness}

The VMP includes the VTA, which contains dopaminergic $(\sim 60 \%)$ and GABAergic ( $\sim 35 \%)$ neurons (Oishi and Lazarus, 2017). Because VTA dopaminergic neurons are implicated in the regulation of wakefulness (Eban-Rothschild et al., 2016; Oishi et al., 2017a), we next selectively ablated these neurons in the VMP to determine whether they contribute to baseline wakefulness in mice. To generate mice with VMP dopaminergic neuron deficiency (DAT-Cre ${ }^{\text {DTA/VMP }}$ mice; Fig. $2 A-C$ ), AAV-FLEX-DTA was microinjected into the VMP of DAT-Cre mice expressing the Cre protein exclusively in dopaminergic neurons (Bäckman et al., 2006). Mice expressing humanized Renilla reniformis-derived green fluorescent protein (hrGFP) in VMP dopaminergic neurons were generated as a control (DAT-Cre ${ }^{\text {hrGFP/VMP }}$ mice; Fig. $2 D, E)$. The number of cells positive for $\mathrm{TH}$, a marker of dopaminergic neurons, was decreased by $94 \%$ in the VMP of DATCre ${ }^{\text {DTA/VMP }}$ mice compared with DAT-Cre ${ }^{\text {hrGFP/VMP }}$ mice $\left(t_{(10)}=9.30, p<0.0001\right.$, unpaired $t$ test; Fig. $\left.2 F\right)$. Compared with the DAT-Cre ${ }^{\text {hrGFP/VMP }}$ mice, DAT-Cre ${ }^{\text {DTA/VMP }}$ mice exhibited no significant differences in the time course of wakefulness $\left(F_{(1,10)}=0.0135, p=0.91\right.$, ANOVA; Fig. $\left.2 G\right)$, SWS $\left(F_{(1,10)}=\right.$ $0.0013, p=0.97$, ANOVA; Fig. $2 H)$, or REMS $\left(F_{(1,10)}=0.137\right.$, $p=0.72$, ANOVA; Fig. $2 I$ ) or in the mean duration (light period wakefulness: $t_{(10)}=1.02, p=0.33$; dark period wakefulness: $t_{(10)}=0.957, p=0.36$; light period SWS: $t_{(10)}=0.851, p=0.41$; dark period SWS: $t_{(10)}=0.307, p=0.77$; light period REMS: $t_{(10)}=1.09, p=0.30$; dark period REMS: $t_{(10)}=1.72, p=0.12$, unpaired $t$ test; Fig. $2 J-L$ ) and number (light period wakefulness: $t_{(10)}<0.01, p>0.99$; dark period wakefulness: $t_{(10)}=0.727, p=$ 0.48 ; light period SWS: $t_{(10)}=0.026, p=0.98$; dark period 

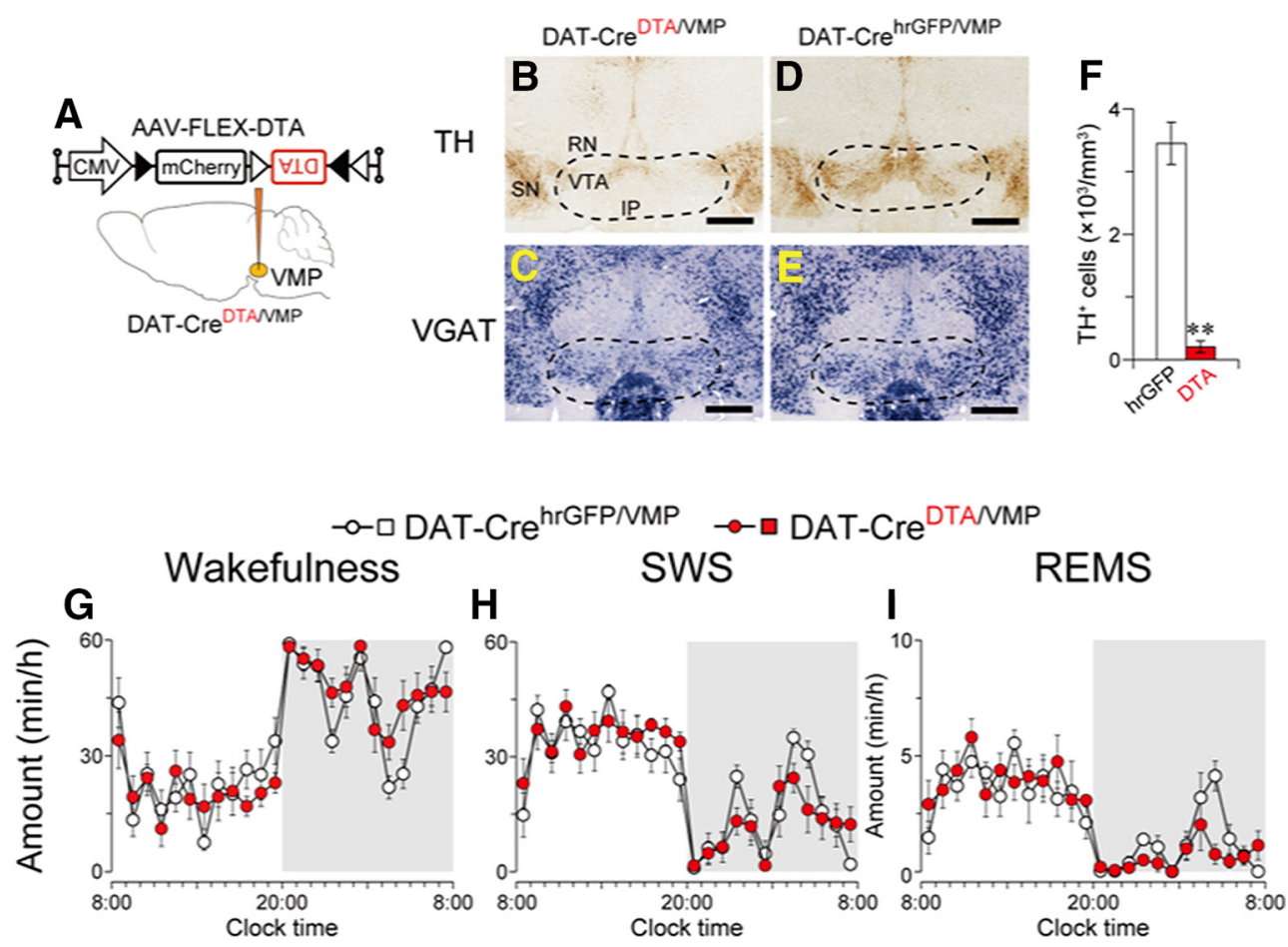

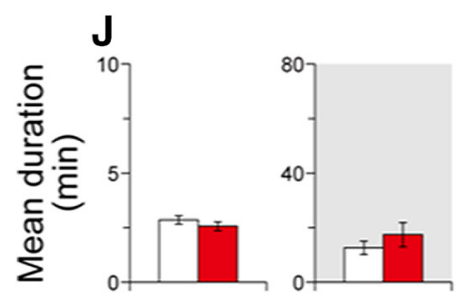

K
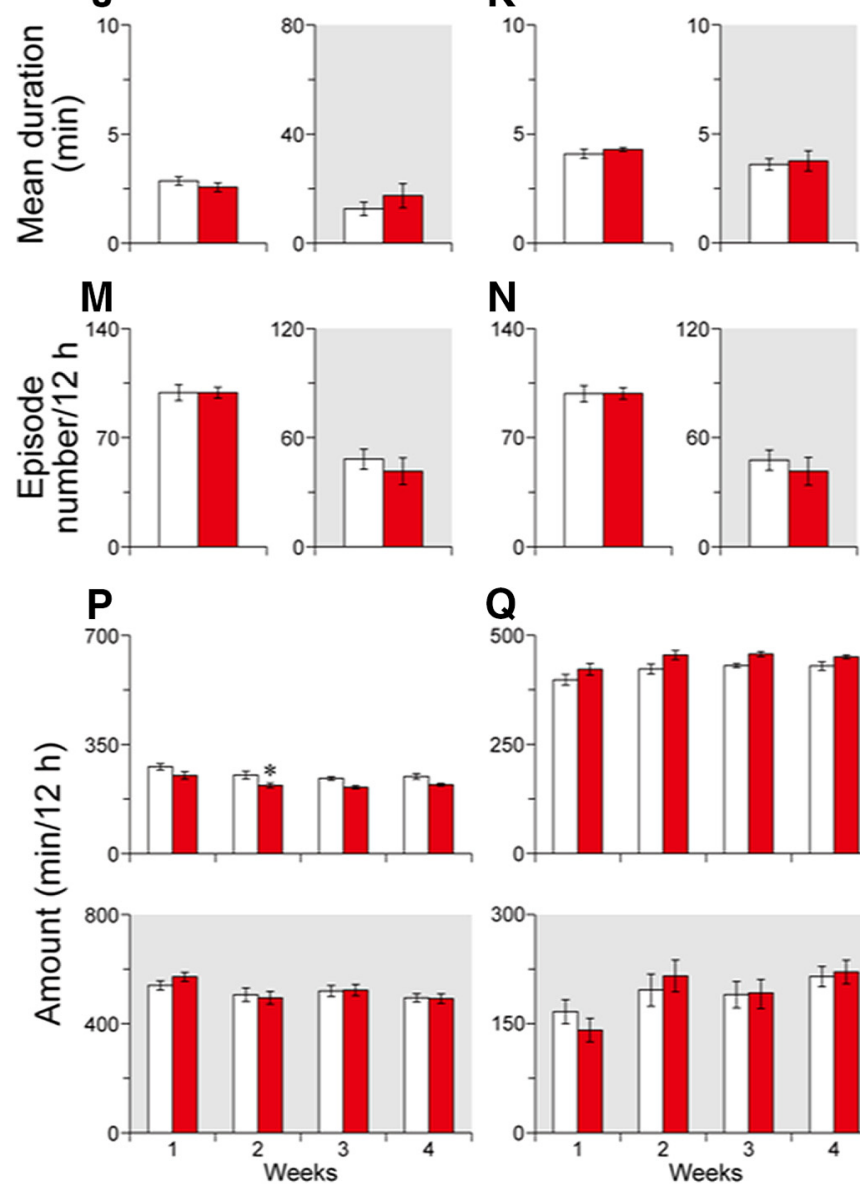

N

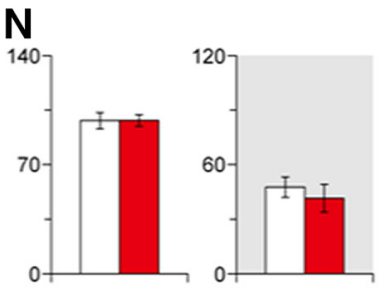

Q
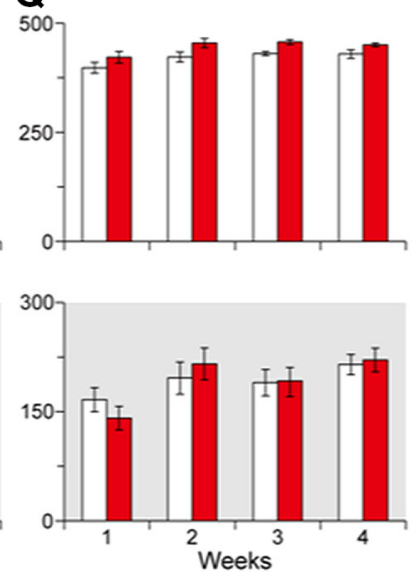

L

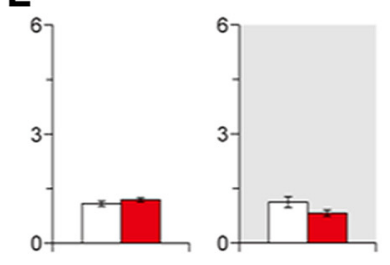

0

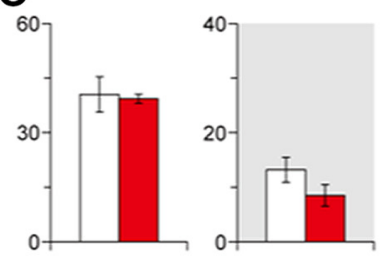

R
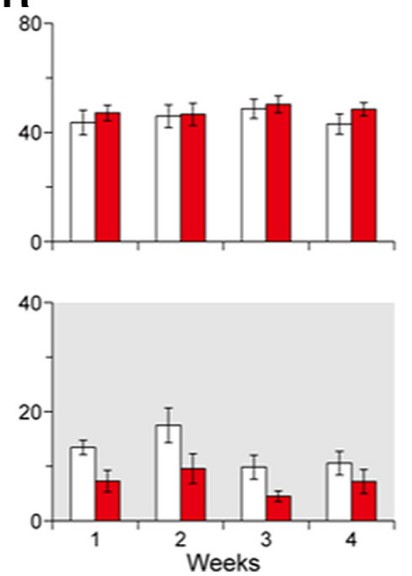

Figure 2. Ablation of the VMP dopaminergic neurons had little to no effect on wakefulness. $\boldsymbol{A}, \mathrm{DAT}$-Cre mice were injected with AAV-FLEX-DTA into the VMP. $\boldsymbol{B}$ - $\boldsymbol{E}$, Brain sections stained against TH ( $\boldsymbol{B}, \boldsymbol{D})$ or VGAT mRNA (C, $\boldsymbol{E})$ from mice injected with AAV-FLEX-DTA (DAT-Cre ${ }^{\text {DTA/NMP }}$ mice; $\boldsymbol{B}, \boldsymbol{C}$ ) or AAV-FLEX-hrGFP (DAT-Cre ${ }^{\text {hrGFP/vMP }}$ mice; $\left.\boldsymbol{D}, \boldsymbol{E}\right)$ to confirm that the VMP dopaminergic neurons were selectively ablated in DAT-Cre mice. Dashed line delineates the area with loss of dopaminergic neurons in a DAT-Cre ${ }^{\text {DTA/VMP }}$ mouse. Scale bar, $500 \mu \mathrm{m}$. $\boldsymbol{F}$, Number of neurons expressing TH in the VMP of mice injected with AAV. $\mathbf{G}-\boldsymbol{I}$, Time course of hourly wakefulness $(\boldsymbol{G})$, SWS $(\boldsymbol{H})$, and REMS $(\boldsymbol{I})$ at 1 week after surgery. $\boldsymbol{J}-\mathbf{0}$, Ablation of the VMP dopaminergic neurons changed neither the mean duration $(\boldsymbol{J}-\boldsymbol{L})$ nor the number $(\boldsymbol{M}-\mathbf{0})$ of each episode. $\boldsymbol{P}-\boldsymbol{R}$, Total amount of wakefulness $(\boldsymbol{P})$, SWS $(\boldsymbol{Q})$, and REMS $(\boldsymbol{R})$ for $12 \mathrm{~h}$. White and gray background in each panel indicate light and dark periods, respectively. ${ }^{*} p<0.05,{ }^{* *} p<0.01$ compared with DAT-Cre ${ }^{\text {hrGFP/NMP }}$ mice. Data are presented as the mean \pm SEM $(n=6)$. RN, Red nucleus; SN, substantia nigra; IP, interpeduncular nucleus. 

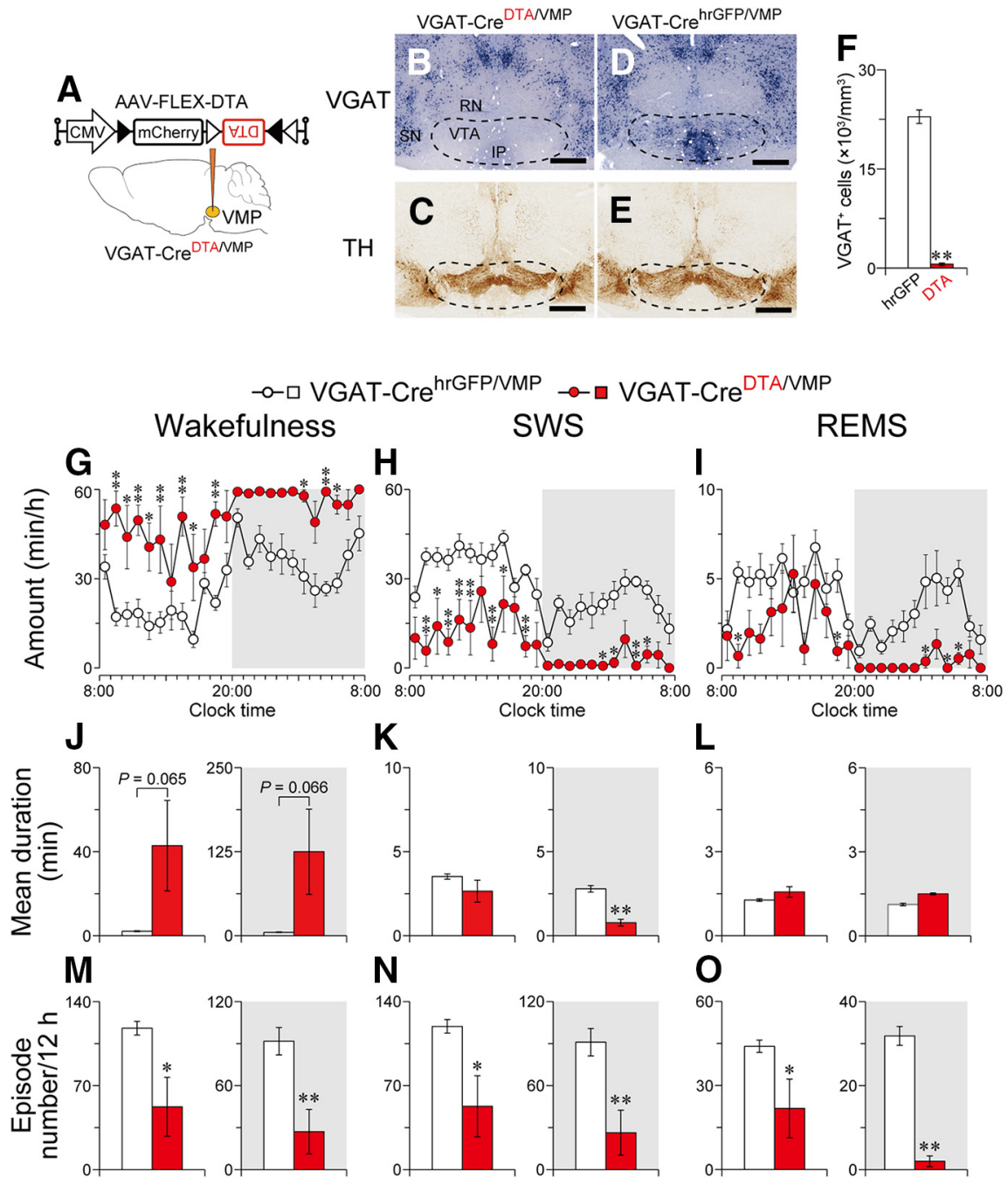

$\mathbf{N}$
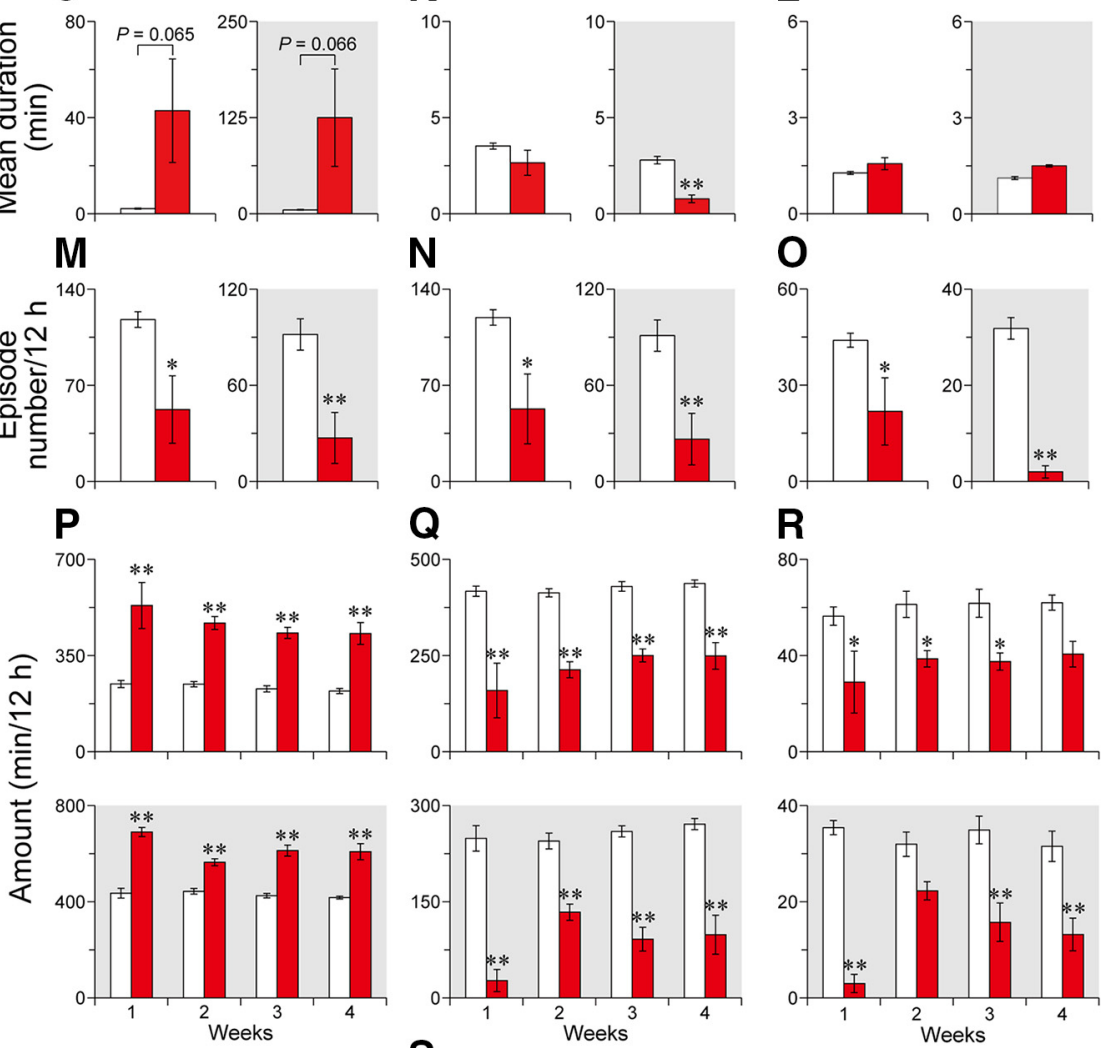

${ }_{500}$

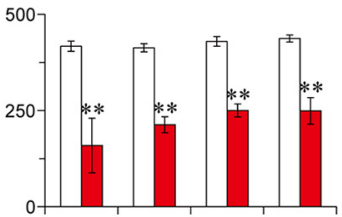

$\mathbf{R}$
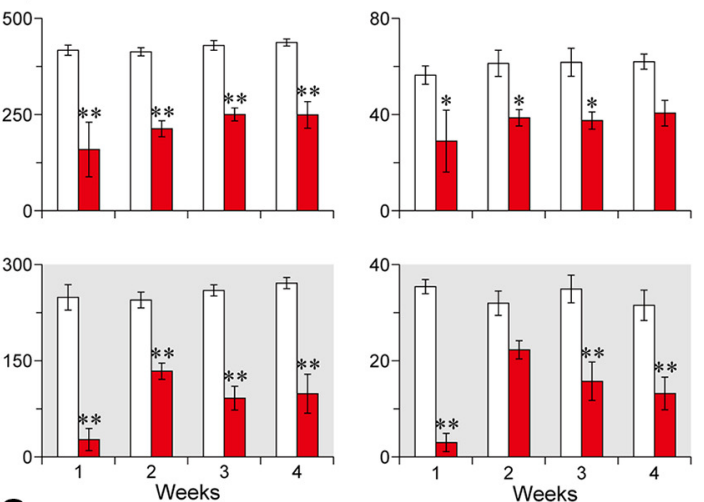

$\mathrm{S}$

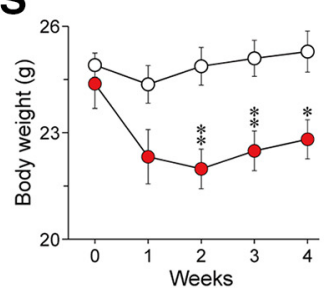

SWS: $t_{(10)}=0.654, p=0.53$; light period REMS: $t_{(10)}=0.232, p=0.82$; dark period REMS: $t_{(10)}=1.56, p=0.15$, unpaired $t$ test; Fig. 2M-O) of each episode at 1 week after surgery. Except for a modest decrease in wakefulness during the light period in the second week after surgery, the total amount of wakefulness, SWS, or REMS during the $12 \mathrm{~h}$ light or dark periods was unchanged for up to 4 weeks after surgery (light period wakefulness: $F_{(1,10)}=13.7, p=0.0041$; dark period wakefulness: $F_{(1,10)}=0.0457, p=0.84$; light period SWS: $F_{(1,10)}=6.54, p=$ 0.029; dark period SWS: $F_{(1,10)}=0.0007$, $p=0.98$; light period REMS: $F_{(1,10)}=$ 0.430, $p=0.53$; dark period REMS: $F_{(1,10)}=6.38, p=0.030$, ANOVA followed by Sidak's post hoc comparisons; Fig. $2 P-R)$. These findings suggest that dopaminergic neurons in the VMP are not required for the sleep-wake patterns of mice.

VMP GABAergic neuron deficiency increases wakefulness in mice

We next evaluated the effect of GABAergic neuron ablation in the VMP. DTA was focally expressed in the VMP by stereotaxic microinjection of AAV-FLEX-DTA into the VMP of VGAT-Cre mice (VGATCre ${ }^{\text {DTA/VMP }}$ mice) selectively expressing the Cre protein in GABAergic neurons (Vong et al., 2011) (Fig. 3A-C). Control mice expressed hrGFP in the VMP GABAergic neurons (VGAT-Cre ${ }^{\text {hrGFP/VMP }}$ mice; Fig. $3 D, E)$. The number of cells positive for VGAT mRNA was decreased by $97 \%$ in the VMP of VGAT-Cre ${ }^{\text {DTA/VMP }}$ mice compared with VGAT-Cre ${ }^{\text {hrGFP/VMP }}$ mice $\left(t_{(9)}=19.7, p<0.0001\right.$, unpaired $t$ test; Fig. $3 F)$. Compared with VGATCre ${ }^{\text {hrGFP/VMP }}$ mice, VGAT-Cre ${ }^{\text {DTA/VMP }}$ mice had largely increased wakefulness throughout the entire day $\left(F_{(1,9)}=31.2\right.$, $p=0.0003$, ANOVA; Fig. $3 G)$. Concomitantly, VGAT-Cre ${ }^{\text {DTA/VMP }}$ mice exhibited lower amounts of SWS $\left(F_{(1,9)}=31.8, p=\right.$

$\leftarrow$

wakefulness $(\boldsymbol{G})$, SWS $(\boldsymbol{H})$, and REMS $(\boldsymbol{I})$ amount at 1 week after surgery. $\boldsymbol{J}-\mathbf{0}$, Ablation of the VMP GABAergic neurons induced a longer mean duration of wake episodes $(\boldsymbol{J}-\boldsymbol{L})$, whereas the mean number of each episode was smaller ( $\boldsymbol{M}$ O). $\boldsymbol{P}$ - $\boldsymbol{R}$, Total amount of wakefulness ( $\boldsymbol{P}$ ), SWS ( $\boldsymbol{Q})$, and REMS $(\boldsymbol{R})$ for $12 \mathrm{~h}$. White and gray background in each panel indicate light and dark periods, respectively. S, Time course of body weight changes. ${ }^{*} p<0.05,{ }^{* *} p<0.01$, compared with VGAT-Cre ${ }^{\text {hrGFPNMPP }}$ mice. Data are presented as the mean \pm SEM $[n=5-6$, except for $L$ ( $n=4$ for light and 2 for dark) because of the absence of REMS in some VGAT-Cre ${ }^{\text {DTANMMP }}$ mice, and $\mathbf{S}(n=8-9)]$. RN, Red nucleus; $\mathrm{SN}$, substantia nigra; $\mathbb{I P}$, interpeduncular nucleus.

Figure 3. Ablation of the VMP GABAergic neurons strongly increased wakefulness. $A$, VGAT-Cre mice were injected with AAV-FLEX-DTA into the VMP. $\boldsymbol{B}-\boldsymbol{E}$, Brain sections stained against VGAT mRNA $(\boldsymbol{B}, \boldsymbol{D})$ or TH $(\boldsymbol{C}, \boldsymbol{E})$ in mice injected with AAV-FLEXDTA (VGAT-Cre ${ }^{\text {DTA/NMP }}$ mice; $\boldsymbol{B}, \boldsymbol{C}$ ) or AAV-FLEX-hrGFP (VGAT-Cre ${ }^{\text {hrGFP/NMP }}$ mice; $\left.\boldsymbol{D}, \boldsymbol{E}\right)$ to confirm that the VMP GABAergic neurons were selectively ablated in VGAT-Cre mice. Dashed line delineates the area with loss of GABAergic neurons in a VGAT-Cre ${ }^{\text {DTA/VMP }}$ mouse. Scale bar, $500 \mu \mathrm{m}$. $\boldsymbol{F}$, Number of neurons expressing VGAT in the VMP of mice injected with AAV. $\mathbf{G}-\boldsymbol{I}$, Time course of 
0.0003, ANOVA; Fig. $3 H)$ and REMS $\left(F_{(1,9)}=18.0, p=0.0022\right.$, ANOVA; Fig. $3 I)$. The mean duration of wake episodes in VGAT-Cre ${ }^{\text {DTA/VMP }}$ mice in the light and dark periods was 20.2 and 24.6 times longer, respectively, than that in VGATCre ${ }^{\text {hrGFP/VMP }}$ mice, although the difference was not statistically significant (light period: $t_{(9)}=2.10, p=0.065$, unpaired $t$ test; dark period: $t_{(9)}=2.10, p=0.066$, unpaired $t$ test; Fig. $3 J$ ), whereas the mean number of wake episodes in the light and dark period was $56 \%\left(t_{(9)}=2.84\right.$, $p=0.019$, unpaired $t$ test) and 70\% $\left(t_{(9)}=3.59, p=0.0059\right.$, unpaired $t$ test $)$ lower, respectively (Fig. $3 M$ ). These results suggest that ablating VMP GABAergic neurons efficiently consolidates wakefulness, similar to the effects of nonselective VMP ablation in animals (Fig. $1 H, K)$. For the mean duration, only SWS during the dark period was significantly reduced (light period SWS: $t_{(9)}=1.41, p=0.19$; dark period SWS: $t_{(9)}=7.25, p<0.0001$; unpaired $t$ test; Fig. $3 K$ ), whereas the episode numbers of both SWS and REMS were decreased in VGAT-Cre ${ }^{\text {DTA/VMP }}$ mice during both light conditions (light period SWS: $t_{(9)}=2.80, p=0.021$; dark period SWS: $t_{(9)}=3.56, p=0.0061$; light period REMS: $t_{(9)}=2.27, p=0.049$; dark period REMS: $t_{(9)}=10.9, p<0.0001$, unpaired $t$ test; Fig. $3 N, O)$. The increased wakefulness in the VGAT-Cre ${ }^{\text {DTA/VMP }}$ mice was maintained in both the light and dark periods for at least 4 weeks (light period: $F_{(1,9)}=47.1, p<0.0001$; dark period: $F_{(1,9)}=98.1, p<0.0001$, ANOVA; Fig. $3 P$ ). The SWS and REMS amounts were concomitantly lower in VGAT-Cre ${ }^{\text {DTA/VMP }}$ mice (light period SWS: $F_{(1,9)}=50.4, p<0.0001$; dark period SWS: $F_{(1,9)}=86.5, p<0.0001$; light period REMS: $F_{(1,9)}=11.9, p=$ 0.0072; dark period REMS: $F_{(1,9)}=55.3, p<0.0001$, ANOVA; Fig. $3 Q, R)$. Despite the long-lasting wake time, the VGAT-Cre ${ }^{\text {DTA/VMP }}$ mice appeared healthy although the body weight was slightly, but significantly, lower than that of VGAT-Cre ${ }^{\text {hrGFP/VMP }}$ mice $\left(F_{(1,15)}=\right.$ 8.42, $p=0.011$, ANOVA; Fig. $3 S)$. These findings suggest that the VMP GABAergic neurons are essential for maintaining sleep-wake patterns in mice.

\section{Dopamine mediates the increased wakefulness in mice with VMP GABAergic neuron deficiency}

We next investigated the molecular mechanisms of increased wakefulness in the VGAT-Cre ${ }^{\text {DTA/VMP }}$ mice using pharmacologic methods. Because the VMP comprises the VTA and rostromedial tegmental nucleus GABAergic neurons projecting to midbrain dopaminergic neurons (Jhou et al., 2009b; Omelchenko and Sesack, 2009), we tested whether the dopaminergic system is involved in the increased wakefulness in VGATCre ${ }^{\text {DTA/VMP }}$ mice. Previous studies suggested that dopamine produces wakefulness via D1 and D2 receptors, so we treated mean $\pm \operatorname{SEM}(n=5-8)$.

\section{B VGAT-Cre ${ }^{\text {hrGFPNMP }}$}

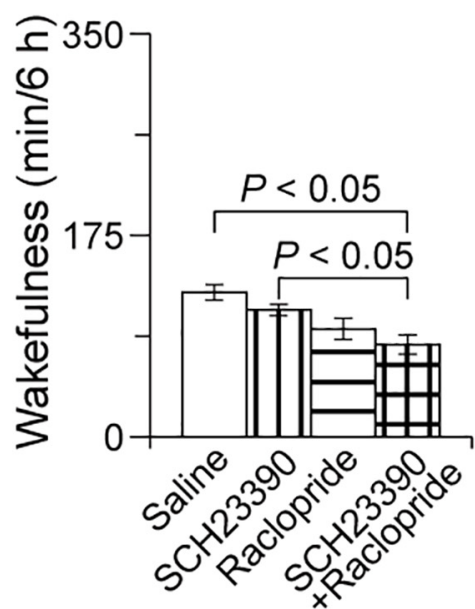

D VGAT-Cre ${ }^{\text {hrGFPNMP }}$

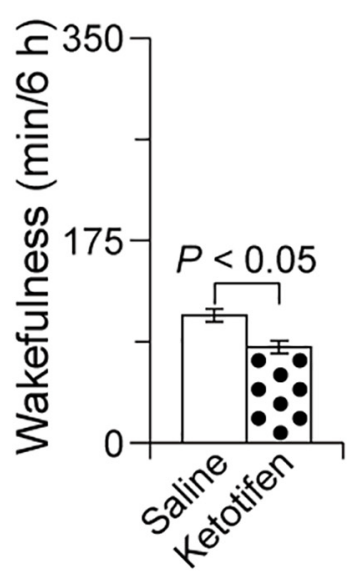

Figure 4. Dopamine receptor antagonists suppressed wakefulness in mice with an absence of GABAergic neurons in the VMP. antagonists (SCH23390 and/or raclopride; $\boldsymbol{A}, \boldsymbol{B})$ or the histamine $\mathrm{H} 1$ receptor antagonist ketotifen $(\boldsymbol{C}, \boldsymbol{D})$. Data are presented as the

VGAT-Cre ${ }^{\text {DTA/VMP }}$ or VGAT-Cre ${ }^{\text {hrGFP/VMP }}$ mice at 10:00 with either the selective dopamine D1 receptor antagonist SCH23390 at $0.03 \mathrm{mg} \mathrm{kg}^{-1}$, the selective dopamine D2/D3 receptor antagonist raclopride at $2 \mathrm{mg} \mathrm{kg}^{-1}$, a mixture of SCH23390 and raclopride, or saline as a vehicle control. The mixture of SCH23390 and raclopride decreased wakefulness for $6 \mathrm{~h}$ in VGAT-Cre ${ }^{\text {DTA/ }}$ VMP and VGAT-Cre ${ }^{\text {hrGFP/VMP }}$ mice after the drug injection, while neither SCH23390 nor raclopride alone significantly affected wakefulness in the VGAT-Cre ${ }^{\text {DTA/VMP }}$ and control mice, suggesting that dopamine receptors mediate wakefulness under baseline conditions and in cases of VMP GABAergic neuron deficiency (Fig. $4 A: F_{(2.06,14.4)}=8.34, p=0.0037$; Fig. $4 B: F_{(2.09,10.4)}=58.3$, $p=0.0057$, ANOVA). In contrast, the histamine $\mathrm{H} 1$ receptor antagonist ketotifen at $10 \mathrm{mg} \mathrm{kg}^{-1}$ decreased wakefulness in VGAT-Cre ${ }^{\text {hrGFP/VMP }}$ mice $\left(t_{(4)}=3.50, p=0.025\right.$, paired $t$ test; Fig. $4 D)$, but did not affect wakefulness in VGAT-Cre ${ }^{\text {DTA/VMP }}$ mice $\left(t_{(5)}=0.18, p=0.86\right.$, paired $t$ test; Fig. $\left.4 C\right)$, suggesting that histamine $\mathrm{H} 1$ receptors do not play an important role in the increased wakefulness in mice with an absence of GABAergic neurons in the VMP. 

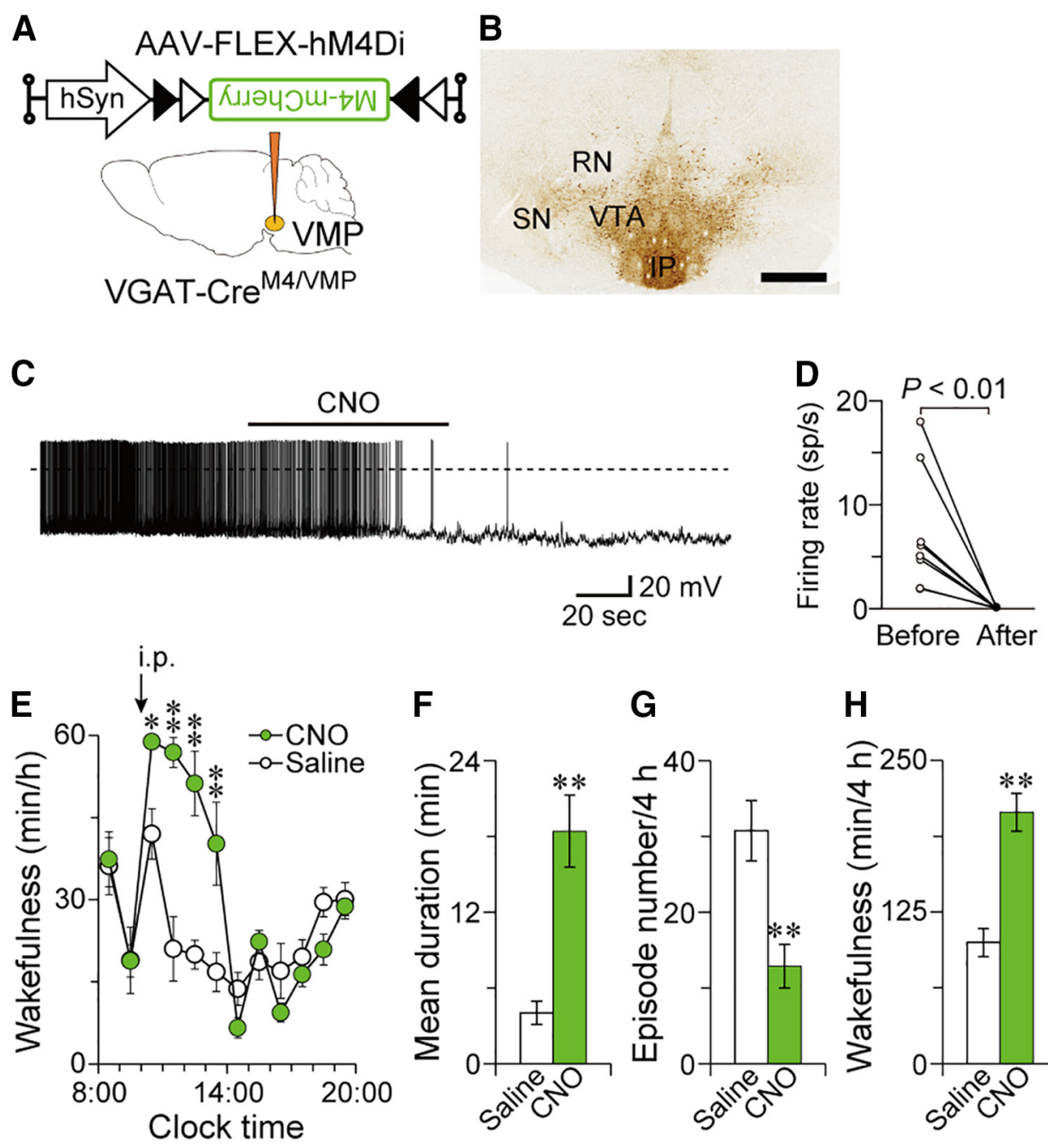

G

H
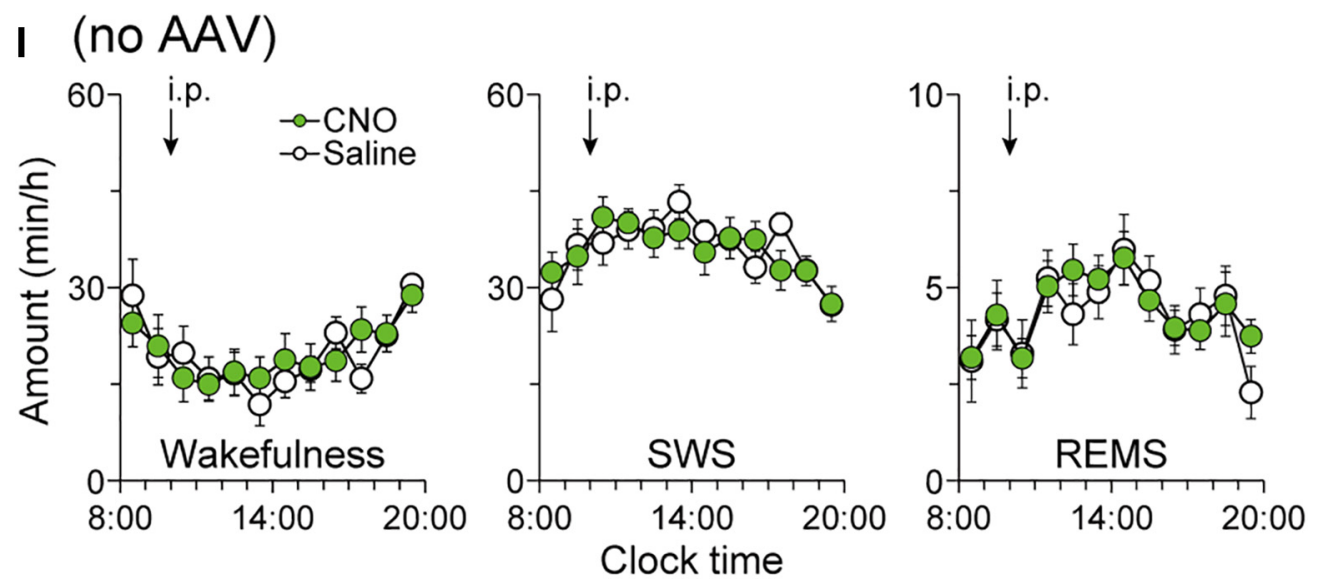

Figure 5. Chemogenetic inhibition of the VMP GABAergic neurons increased wakefulness. A, VGAT-Cre mice were injected with AAV-FLEX-hM4Di-mCherry into the VMP (VGAT-Cre ${ }^{\text {M4/VMP }}$ mice). $B$, Brain sections were stained against mCherry to confirm that the hM4Di-mCherry protein was expressed in the VMP. Scale bar, $500 \mu \mathrm{m}$. C, Representative trace of current-clamp recording from a hM4Di-expressing neuron. The solid bar indicates the duration of $5 \mu \mathrm{M}$ CNO application. The dotted line denotes $0 \mathrm{mV}$. D, Mean firing rate of hM4Di-expressing neurons before and after CNO application ( $n=8$ cells from 3 mice). Data obtained from the same cell are connected with a line. $\boldsymbol{E}$, Time course of hourly wakefulness. $\boldsymbol{F}-\boldsymbol{H}$, Chemogenetic inhibition increased the mean wake episode duration $(\boldsymbol{F})$ and total amount of wakefulness $(\boldsymbol{H})$, whereas the number of wake episodes $(\boldsymbol{G})$ was reduced for $4 \mathrm{~h}$ after $3 \mathrm{mg} \mathrm{kg}^{-1} \mathrm{CNO}$ injection. $\boldsymbol{I}$, CNO application did not affect sleep-wake amounts in naive VGAT-Cre mice. ${ }^{*} p<0.05,{ }^{* *} p<0.01$ compared with saline. Data are presented as the mean \pm SEM $(n=7-8)$. RN, Red nucleus; SN, substantia nigra; IP, interpeduncular nucleus.

\section{Chemogenetic inhibition of VMP GABAergic neurons} increases wakefulness

To determine whether inhibition of VMP GABAergic neurons also affects sleep-wake regulation in mice, we chemogenetically inhibited these neurons in the VMP of VGAT-Cre mice (VGAT$\mathrm{Cre}^{\mathrm{M} 4 / \mathrm{VMP}}$ mice; Fig. $\left.5 A, B\right)$ using inhibitory designer receptors exclusively activated by designer drugs (DREADD) hM4Di, which suppress neuronal activity when the ligand CNO is applied 
(Urban and Roth, 2015). Whole-cell patch-clamp recordings in acute slices were performed to test the response of a single hM4Di-expressing VMP neuron to CNO application in a VGAT-Cre ${ }^{\mathrm{M} 4 / \mathrm{VMP}}$ mouse. We bath-applied $5 \mu \mathrm{M} \mathrm{CNO}$ to the brain slices and found that $\mathrm{CNO}$ reduced the firing rate of VMP neurons expressing hM4Di from $7.4 \pm 2.1$ to $0.04 \pm 0.03$ spikes/s $\left(t_{(7)}=3.55, p=0.0094\right.$, paired $t$ test; Fig. $5 C, D)$. Intraperitoneal administration of $3 \mathrm{mg} \mathrm{kg}^{-1} \mathrm{CNO}$ to VGAT$\mathrm{Cre}^{\mathrm{M} 4 / \mathrm{VMP}}$ mice at 10:00, when mice spend most of their time asleep, increased wakefulness for $4 \mathrm{~h}$ after the injection (Fig. $5 E: F_{(1,7)}=5.99, p=0.044$, ANOVA; Fig. $5 H: t_{(7)}=7.19, p=0.0002$, paired $t$ test). $\mathrm{CNO}$ increased the mean wake episode duration by 4.6 -fold $\left(t_{(7)}=5.49, p=\right.$ 0.0009 , paired $t$ test) and decreased the mean episode number by $58 \%\left(t_{(7)}=\right.$ $4.26, p=0.0038$, paired $t$ test) (Fig. $5 F, G$ ), similar to that in VGAT-Cre ${ }^{\text {DTA/VMP }}$ mice (Fig. $3 J, M$ ). CNO administration at 10:00 did not affect the sleep-wake behavior of naive VGAT-Cre mice (wakefulness: $F_{(1,6)}=0.14, p=0.72$; SWS: $F_{(1,6)}=1.16$, $p=0.32$; REMS: $F_{(1,6)}=0.65, p=0.45$, ANOVA; Fig. 5I). These results suggest that wakefulness is also increased by transient inhibition of VMP GABAergic neurons.

Blocking dopamine receptors abolishes the increased wakefulness by inhibition of VMP GABAergic neurons

Next, we investigated whether dopamine receptors contribute to the increased wakefulness after chemogenetic inhibition of VMP GABAergic neurons using SCH23390 and raclopride. VGAT-Cre ${ }^{\text {M4/VMP }}$ mice were pretreated with saline, $0.03 \mathrm{mg}$ $\mathrm{kg}^{-1} \mathrm{SCH} 23390,2 \mathrm{mg} \mathrm{kg}^{-1}$ raclopride, or a mixture of SCH 23390 and raclopride 30 min before the CNO injection at 10:00. In VGAT-Cre ${ }^{\mathrm{M} 4 / \mathrm{VMP}}$ mice pretreated with SCH23390 or raclopride, CNO still increased wakefulness for several hours, although the total amount of wakefulness for $4 \mathrm{~h}$ after CNO injection was significantly decreased by both antagonists (Fig. $6 A: F_{(1,6)}=29.4, p=0.0016$; Fig. $6 B: F_{(1,6)}=38.6, p=0.0008$; Fig. $6 C$ : $F_{(1,6)}=25.2, p=0.0024$; Fig. $6 E$ : $F_{(3,18)}=72.9, p<0.0001$, ANOVA). Conversely, CNO injection did not induce wakefulness when mice were pretreated with the mixture of SCH23390 and raclopride (Fig. $6 D: F_{(1,6)}=22.9$, $p=0.003$, ANOVA; Fig. $6 E)$, indicating that dopamine receptors mediate for the wake effect after inhibition of VMP GABAergic neurons.
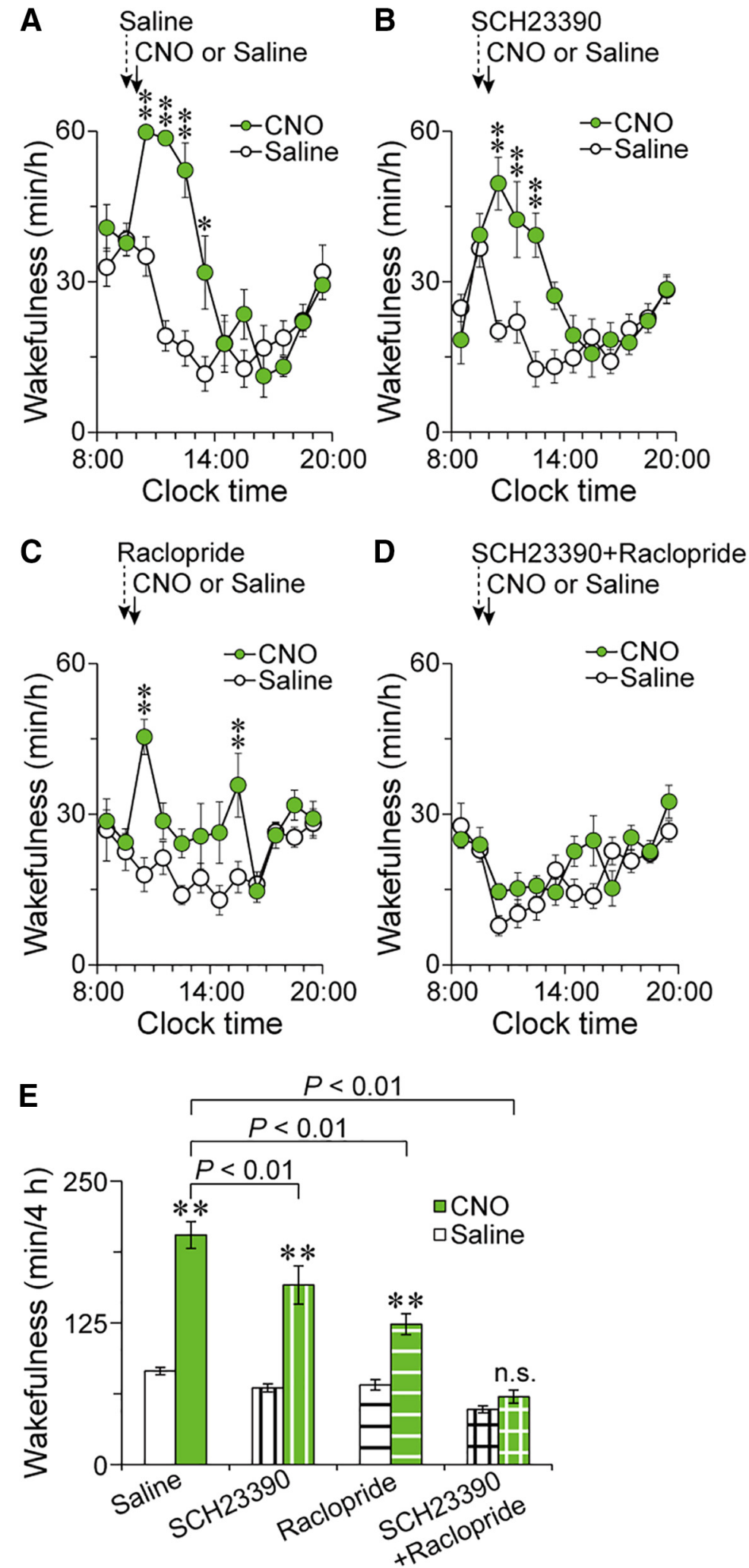

Figure 6. Dopamine receptor antagonists blocked the wake effect caused by inhibition of the VMP GABAergic system. $\boldsymbol{A}-\boldsymbol{D}$, Time course of wakefulness in VGAT-Cre ${ }^{\mathrm{M} 4 / \mathrm{VMP}}$ mice administered CNO after pretreatment with saline $(\boldsymbol{A}), \mathrm{SCH} 23390(\boldsymbol{B})$, raclopride (C), or SCH23390 and raclopride (D). $\boldsymbol{E}$, Total amount of wakefulness for $4 \mathrm{~h}$ after injecting CNO in VGAT-Cre ${ }^{\text {M4/VMP }}$ mice pretreated with dopamine receptor antagonists. ${ }^{*} p<0.05,{ }^{* *} p<0.01$ compared with saline. n.s., Not significant. Data are presented as the mean $\pm \operatorname{SEM}(n=7)$. 

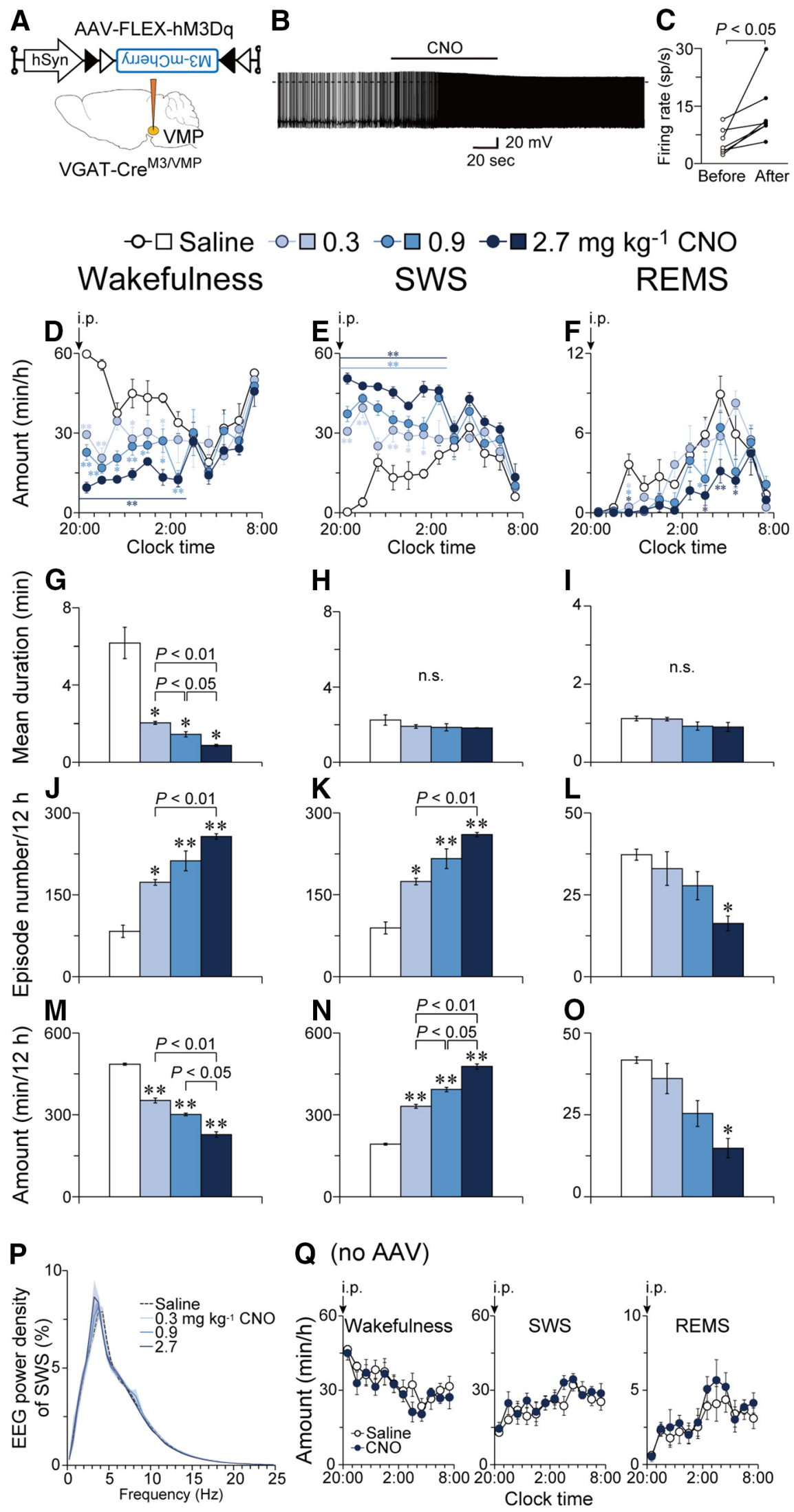

Figure 7. Chemogenetic activation of the VMP GABAergic neurons reduced wakefulness and induced SWS. $\boldsymbol{A}$, VGAT-Cre mice were injected with AAV-FLEX-hM3Dq-mCherry into the VMP (VGAT-Cre ${ }^{\mathrm{M} 3 / \mathrm{VMP}}$ mice). $\boldsymbol{B}$, Representative trace of current-clamp recording from a hM3Dq-expressing neuron. The solid bar indicates the duration of $5 \mu \mathrm{m}$ CNO application. The dotted line denotes $0 \mathrm{mV}$. C, Mean firing rate of hM3Dq-expressing neurons before and after CNO application ( $n=7$ cells from 3 mice). Data obtained from the same cell are connected with a line. $\boldsymbol{D}-\boldsymbol{F}$, Time course of hourly wakefulness $(\boldsymbol{D})$, SWS $(\boldsymbol{E})$, and REMS $(\boldsymbol{F})$. G-0, Mean

\section{Chemogenetic activation of VMP}

GABAergic neurons induces SWS

To further examine the role of VMP

GABAergic neurons in sleep-wake regulation, we introduced an excitatory DREADD hM3Dq that evokes neuronal excitation by administering $\mathrm{CNO}$ to VGAT-Cre mice (VGAT-Cre ${ }^{\mathrm{M} 3 / \mathrm{VMP}}$ mice; Fig. 7A). Whole-cell patch-clamp recordings in acute slices containing the VMP revealed that the application of $5 \mu \mathrm{M}$ $\mathrm{CNO}$ increased the firing rate of hM3Dqexpressing VMP neurons in VGAT$\mathrm{Cre}^{\mathrm{M} 3 / \mathrm{VMP}}$ mice from $5.6 \pm 1.3$ to $13.4 \pm$ 3.0 spikes $/ \mathrm{s}\left(t_{(6)}=2.82, p=0.030\right.$, paired $t$ test; Fig. $7 B, C)$. Intraperitoneal administration of $\mathrm{CNO}$ to VGAT-Cre ${ }^{\mathrm{M} 3 / \mathrm{VMP}}$ mice at 20:00 drastically decreased wakefulness $\left(F_{(3,9)}=259.9, p<0.0001\right.$, ANOVA $)$ and increased SWS $\left(F_{(3,9)}=\right.$ $337.9, p<0.0001$, ANOVA) for $7 \mathrm{~h}$ after the injection (Fig. $7 D, E$ ). Interestingly, $\mathrm{CNO}$ also decreased the amount of REMS $\left(F_{(3,9)}=22.4, p=0.0002\right.$, ANOVA $)$ for up to $10 \mathrm{~h}$ after the injection (Fig. $7 F$ ). $\mathrm{CNO}$ dose-dependently decreased the mean wake episode duration $\left(F_{(1.02,3.05)}=\right.$ $41.9, p=0.0071$, ANOVA; Fig. $7 G)$ for $12 \mathrm{~h}$ after the injection, but did not change the sleep episode duration (Fig. $7 H$ : $F_{(1.39,4.16)}=1.93, p=0.246$; Fig. 7I: $F_{(1.60,4.81)}=1.80, p=0.255$, ANOVA). Conversely, $\mathrm{CNO}$ increased the number of both wake $\left(F_{(1.67,5.02)}=73.2, p=\right.$ 0.0002 , ANOVA; Fig. $7 J)$ and SWS $\left(F_{(1.69,5.07)}=76.2, p=0.0002\right.$, ANOVA; Fig. $7 K)$ episodes, whereas the number of REMS episodes was reduced $\left(F_{(1.74,5.21)}=\right.$ 9.98, $p=0.018$, ANOVA; Fig. $7 L)$. The total amount of each state during the $12 \mathrm{~h}$ after injection indicated that $\mathrm{CNO}$ dosedependently decreased wakefulness $\left(F_{(1.91,5.72)}=259.6, p<0.0001\right.$, ANOVA; Fig. $7 M)$ and REMS $\left(F_{(2.00,5.99)}=22.5\right.$, $p=0.016$, ANOVA; Fig. 7O), and increased SWS $\left(F_{(1.985 .95)}=337.4, p<\right.$ 0.0001, ANOVA; Fig. $7 N$ ). CNO did not change the EEG power spectrum during $\operatorname{SWS}\left(F_{(3,9)}=1.317, p=0.33\right.$, ANOVA; Fig. $7 P$ ). CNO administration at 20:00 did not affect sleep-wake behavior in naive VGAT-Cre mice (wakefulness: $F_{(1,5)}=$ 3.28, $p=0.13$; SWS: $F_{(1,5)}=3.33, p=$ 0.13; REMS: $F_{(1,5)}=3.34, p=0.13$,

episode duration $(\mathbf{G}-\boldsymbol{I})$, number of episodes $(\boldsymbol{J}-\boldsymbol{L})$, and total amount $(\boldsymbol{M}-\boldsymbol{O})$ of wakefulness $(\boldsymbol{G}, \boldsymbol{J}, \boldsymbol{M})$, SWS $(\boldsymbol{H}, \boldsymbol{K}, \boldsymbol{N})$, and $\operatorname{REMS}(\boldsymbol{I}, \mathbf{L}, \mathbf{0})$ for $12 \mathrm{~h}$ after $\mathrm{CN} 0$ injection. $\boldsymbol{P}$, EEG power density during SWS. $\boldsymbol{Q}$, CNO $\left(3 \mathrm{mg} \mathrm{kg}^{-1}\right)$ application did not affect sleep-wake amounts in naive VGAT-Cre mice. ${ }^{*} p<0.05$, ${ }^{* *} p<0.01$ compared with saline. Data are presented as the mean $\pm \operatorname{SEM}(n=4)$. 
A

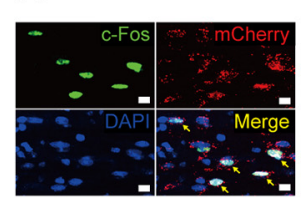

B

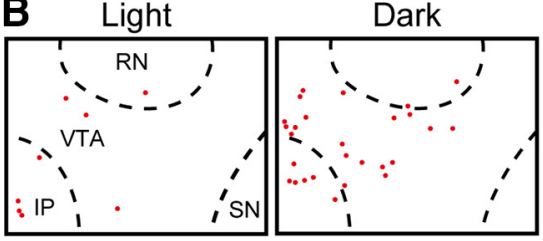

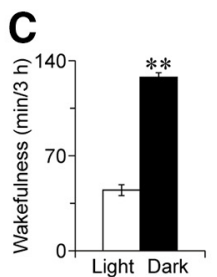

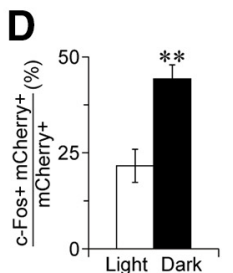

Figure 8. VMP GABAergic neurons exhibited higher c-Fos expression during night. $\boldsymbol{A}$, Example of double-labeled cells (indicated by arrows) for c-Fos (green) and mCherry (GABAergic cells; red) counterstained with DAPI (nuclei; blue) in VGAT-Cre ${ }^{\mathrm{M} 4 / \mathrm{VMP}}$ mice. Scale bar, $10 \mu \mathrm{m}$. $\boldsymbol{B}$, Line drawings showing typical distribution of c-Fos/mCherry double-labeled cells (red circles). $\boldsymbol{C}$, Wakefulness during $3 \mathrm{~h}$ before killing the mice. $\boldsymbol{D}$, Percentage of double-positive neurons for c-Fos and mCherry among mCherry-positive neurons in the VMP. ${ }^{* *} p<0.01$ compared with light period. Data are presented as the mean \pm SEM $(n=8)$. RN, Red nucleus; SN, substantia nigra; IP, interpeduncular nucleus.

ANOVA; Fig. 7Q). These results suggest that chemogenetic activation of VMP GABAergic neurons decreased wakefulness by disrupting the maintenance of wake episodes, likely by inducing SWS.

\section{VMP GABAergic neurons are active during the active period} Finally, we examined the patterns of spontaneous activity of the VMP GABAergic neurons by immunohistochemical investigation of the expression of c-Fos, a marker of neuronal activation, in VGAT-Cre ${ }^{\mathrm{M} 4 / \mathrm{VMP}}$ mice (Fig. $8 \mathrm{~A}, \mathrm{~B}$ ). Mice that were killed during the dark period at 24:00 spent more time $(128 \pm 3.3 \mathrm{~min})$ awake during the $3 \mathrm{~h}$ before being killed than mice that were killed during the light period at 12:00 when they woke $45 \pm 4.0$ min during the $3 \mathrm{~h}$ before they were killed $\left(t_{(14)}=15.9, p<\right.$ 0.0001 , unpaired $t$ test; Fig. $8 C$ ). Double labeling for c-Fos and mCherry revealed that mice killed during the dark period had a markedly higher number of hM4Di-mCherry-positive VMP neurons expressing c-Fos $(44 \pm 3.7 \%)$ than mice that were killed during the light period with c-Fos expression observed in $22 \pm$ $4.3 \%$ of hM4Di-mCherry-positive VMP neurons $\left(_{(14)}=3.99\right.$, $p=0.0013$, unpaired $t$ test; Fig. $8 D$ ). These results suggest that the activity of VMP GABAergic neurons is higher during the active period than during the inactive period.

\section{Discussion}

Ablation of cells in the VMP led to a severe and long-lasting (at least 4 weeks) wake effect in mice, consistent with previous reports that nonspecific cytotoxic lesions of ventral areas in the midbrain and pons of cats (Lai et al., 1999) increases wakefulness. Further analysis of the neuronal and molecular mechanisms of the VMP involved in regulating wakefulness revealed that deficiency or inhibition of VMP GABAergic neurons promotes wakefulness through dopamine receptors. Activation of VMP GABAergic neurons strongly induced SWS and reduced wakefulness. These findings suggest that the VMP GABAergic neurons are key components for the control of sleep and wakefulness in mice.

Previous studies indicated that dopamine and its D1 and D2 receptors play a role in promoting wakefulness (Oishi and Lazarus, 2017). Pharmacologic experiments demonstrated that administration of D1 or D2 receptor agonists increases wakefulness (Monti et al., 1988, 1989; Trampus et al., 1991, 1993; Isaac and Berridge, 2003), whereas D1 or D2 receptor antagonists suppress wakefulness (Trampus and Ongini, 1990; Trampus et al., 1991; Ongini et al., 1993; Eder et al., 2003). D2 receptor knockout mice sleep more than WT mice and the arousal effect of modafinil, a widely used wake-promoting drug for treating the sleep disorder narcolepsy, is strongly attenuated in the knock-out mice (Qu et al., 2008). DAT knock-out mice exhibit a higher amount of wakefulness compared with WT mice and are unre- sponsive to modafinil (Wisor et al., 2001). These data implicating a role of dopamine systems in promoting wakefulness, together with our observation that dopamine receptors mediate increased wakefulness after ablation or inhibition of VMP GABAergic neurons, suggest that these inhibitory neurons control wakefulness by suppressing dopaminergic systems.

The circuit between VMP GABAergic and dopamine receptor-expressing neurons for the control of wakefulness remains unclear. The VMP contains the VTA and rostromedial tegmental nucleus, both of which send projections to brain areas containing dopaminergic neurons, including the VTA, substantia nigra, and dorsal raphe, also known as the ventral periaqueductal gray matter (Jhou et al., 2009a,b; Omelchenko and Sesack, 2009; Taylor et al., 2014). Chemogenetic (Oishi et al., 2017a) or optogenetic (Eban-Rothschild et al., 2016; Taylor et al., 2016) activation of VTA dopaminergic neurons strongly promotes wakefulness. Moreover, lesion ( $\mathrm{Lu}$ et al., 2006) and optogenetic activation (Cho et al., 2017) studies revealed that dorsal raphe dopaminergic neurons also play a role in regulating wakefulness. Therefore, the VMP GABAergic neurons may control wakefulness by inhibiting one or more area with wake-active dopaminergic neurons.

Our data suggest that VMP GABAergic neurons are more activated during the dark period, in which mice spend more time in wakefulness compared with the light period. Methodologic limitations must be kept in mind, however, when using c-Fos analysis. The activity of VMP GABAergic neurons may be affected by circadian factors that vary between light and dark periods. In addition, c-Fos expression in neurons likely reflects their activity over several hours and thus c-Fos analysis may lack the temporal resolution to examine frequent behavioral state changes, that is, sleep-wake transitions, in mice. Conversely, c-Fos expression is a classic, well validated marker of neuronal activation used to identify important sleep-wake-related neurons (Sherin et al., 1996; Anaclet et al., 2012; Oishi et al., 2017b). Considering that activation or inhibition of the activity of these neurons decreases or increases wakefulness, respectively, we suspect that the function of VMP GABAergic neurons in sleep-wake regulation may be to inhibit wake-promoting systems during wakefulness to prevent an excessive amount of wakefulness.

The VTA GABAergic neurons increase c-Fos expression after REMS rebound (Maloney et al., 2002; Sapin et al., 2009), suggesting that the neurons are more active during REMS. Surprisingly, however, our results indicate that chemogenetic activation of VMP GABAergic neurons decreases REMS (Fig. 7). Although the function of VTA GABAergic neurons during REMS remains unclear, these neurons may be active during REMS to avoid unnecessary REMS. Alternatively, it is possible that there are one or more GABAergic populations in the VMP (other than VTA) with 
strong REMS-suppressing ability. More detailed neuroanatomic studies are required to clarify the roles of VMP GABAergic neurons in REMS regulation.

VTA dopaminergic neurons have a strong ability to promote wakefulness (Eban-Rothschild et al., 2016; Oishi et al., 2017a), but ablation of VTA dopaminergic neurons in the VMP in mice did not result in obvious changes in wakefulness (Fig. 3). Although this is not consistent with the decreased wakefulness induced by chemogenetic inhibition of VTA dopaminergic neurons reported by another group using a different Cre mouse line (Eban-Rothschild et al., 2016), it is consistent with findings from our previous study that chemogenetic inhibition of VTA dopaminergic neurons did not alter the amount of wakefulness in DAT-Cre mice (Oishi et al., 2017a). A potential reduction in wakefulness caused by a deficiency of VTA dopaminergic neurons may be compensated for by other wake-promoting systems. It is also plausible, however, that VTA dopaminergic neurons are tonically silenced by VMP GABAergic neurons and require salient stimuli to become wake-active (Bromberg-Martin et al., 2010; Eban-Rothschild et al., 2016).

In conclusion, our study revealed a GABAergic ventral midbrain/pons area that regulates sleep-wakefulness through dopaminergic systems. Further studies to examine the neuroanatomic or neurochemical dissociation of the VMP are required to clarify how the level of wakefulness is regulated by VMP GABAergic neurons.

\section{References}

Anaclet C, Lin JS, Vetrivelan R, Krenzer M, Vong L, Fuller PM, Lu J (2012) Identification and characterization of a sleep-active cell group in the rostral medullary brainstem. J Neurosci 32:17970-17976. CrossRef Medline

Bäckman CM, Malik N, Zhang Y, Shan L, Grinberg A, Hoffer BJ, Westphal H, Tomac AC (2006) Characterization of a mouse strain expressing cre recombinase from the $3^{\prime}$ untranslated region of the dopamine transporter locus. Genesis 44:383-390. CrossRef Medline

Bromberg-Martin ES, Matsumoto M, Hikosaka O (2010) Dopamine in motivational control: rewarding, aversive, and alerting. Neuron 68:815-834. CrossRef Medline

Cho JR, Treweek JB, Robinson JE, Xiao C, Bremner LR, Greenbaum A, Gradinaru V (2017) Dorsal raphe dopamine neurons modulate arousal and promote wakefulness by salient stimuli. Neuron 94:1205-1219.e8. CrossRef Medline

Eban-Rothschild A, Rothschild G, Giardino WJ, Jones JR, de Lecea L (2016) VTA dopaminergic neurons regulate ethologically relevant sleep-wake behaviors. Nat Neurosci 19:1356-1366. CrossRef Medline

Eder DN, Zdravkovic M, Wildschiødtz G (2003) Selective alterations of the first NREM sleep cycle in humans by a dopamine D1 receptor antagonist (NNC-687). J Psychiatr Res 37:305-312. CrossRef Medline

Gerashchenko D, Blanco-Centurion CA, Miller JD, Shiromani PJ (2006) Insomnia following hypocretin2-saporin lesions of the substantia nigra. Neuroscience 137:29-36. CrossRef Medline

Guillery RW (2002) On counting and counting errors. J Comp Neurol 447: 1-7. CrossRef Medline

Isaac SO, Berridge CW (2003) Wake-promoting actions of dopamine D1 and D2 receptor stimulation. J Pharmacol Exp Ther 307:386-394. CrossRef Medline

Jhou TC, Geisler S, Marinelli M, Degarmo BA, Zahm DS (2009a) The mesopontine rostromedial tegmental nucleus: a structure targeted by the lateral habenula that projects to the ventral tegmental area of Tsai and substantia nigra compacta. J Comp Neurol 513:566-596. CrossRef Medline

Jhou TC, Fields HL, Baxter MG, Saper CB, Holland PC (2009b) The rostromedial tegmental nucleus (RMTg), a GABAergic afferent to midbrain dopamine neurons, encodes aversive stimuli and inhibits motor responses. Neuron 61:786-800. CrossRef Medline

Jones BE, Bobillier P, Pin C, Jouvet M (1973) The effect of lesions of catecholamine-containing neurons upon monoamine content of the brain and EEG and behavioral waking in the cat. Brain Res 58:157-177. CrossRef Medline
Kaur S, Wang JL, Ferrari L, Thankachan S, Kroeger D, Venner A, Lazarus M, Wellman A, Arrigoni E, Fuller PM, Saper CB (2017) A genetically defined circuit for arousal from sleep during hypercapnia. Neuron 96:11531167.e5. CrossRef Medline

Krashes MJ, Koda S, Ye C, Rogan SC, Adams AC, Cusher DS, Maratos-Flier E, Roth BL, Lowell BB (2011) Rapid, reversible activation of AgRP neurons drives feeding behavior in mice. J Clin Invest 121:1424-1428. CrossRef Medline

Lai YY, Shalita T, Hajnik T, Wu JP, Kuo JS, Chia LG, Siegel JM (1999) Neurotoxic N-methyl-D-aspartate lesion of the ventral midbrain and mesopontine junction alters sleep-wake organization. Neuroscience 90: 469-483. CrossRef Medline

Lazarus M, Shen HY, Cherasse Y, Qu WM, Huang ZL, Bass CE, WinskySommerer R, Semba K, Fredholm BB, Boison D, Hayaishi O, Urade Y, Chen JF (2011) Arousal effect of caffeine depends on adenosine A2A receptors in the shell of the nucleus accumbens. J Neurosci 31:1006710075. CrossRef Medline

Lu J, Jhou TC, Saper CB (2006) Identification of wake-active dopaminergic neurons in the ventral periaqueductal gray matter. J Neurosci 26:193-202. CrossRef Medline

Maloney KJ, Mainville L, Jones BE (2002) c-fos expression in dopaminergic and GABAergic neurons of the ventral mesencephalic tegmentum after paradoxical sleep deprivation and recovery. Eur J Neurosci 15:774-778. CrossRef Medline

Monti JM, Hawkins M, Jantos H, D’Angelo L, Fernandez M (1988) Biphasic effects of dopamine D-2 receptor agonists on sleep and wakefulness in the rat. Psychopharmacology (Berl) 95:395-400. Medline

Monti JM, Jantos H, Fernández M (1989) Effects of the selective dopamine D-2 receptor agonist, quinpirole on sleep and wakefulness in the rat. Eur J Pharmacol 169:61-66. CrossRef Medline

Oishi Y, Lazarus M (2017) The control of sleep and wakefulness by mesolimbic dopamine systems. Neurosci Res 118:66-73. CrossRef Medline

Oishi Y, Takata Y, Taguchi Y, Kohtoh S, Urade Y, Lazarus M (2016) Polygraphic recording procedure for measuring sleep in mice. J Vis Exp 107: e53678. CrossRef Medline

Oishi Y, Suzuki Y, Takahashi K, Yonezawa T, Kanda T, Takata Y, Cherasse Y, Lazarus M (2017a) Activation of ventral tegmental area dopamine neurons produces wakefulness through dopamine D2-like receptors in mice. Brain Struct Funct 222:2907-2915. CrossRef Medline

Oishi Y, Xu Q, Wang L, Zhang BJ, Takahashi K, Takata Y, Luo YJ, Cherasse Y, Schiffmann SN, de Kerchove d'Exaerde A, Urade Y, Qu WM, Huang ZL, Lazarus M (2017b) Slow-wave sleep is controlled by a subset of nucleus accumbens core neurons in mice. Nat Commun 8:734. CrossRef Medline

Omelchenko N, Sesack SR (2009) Ultrastructural analysis of local collaterals of rat ventral tegmental area neurons: GABA phenotype and synapses onto dopamine and GABA cells. Synapse 63:895-906. CrossRef Medline

Ongini E, Bonizzoni E, Ferri N, Milani S, Trampus M (1993) Differential effects of dopamine D-1 and D-2 receptor antagonist antipsychotics on sleep-wake patterns in the rat. J Pharmacol Exp Ther 266:726-731. Medline

Paxinos G, Franklin K (2001) The mouse brain in stereotaxic coordinates. San Diego, CA: Academic.

Qu WM, Huang ZL, Xu XH, Matsumoto N, Urade Y (2008) Dopaminergic D1 and D2 receptors are essential for the arousal effect of modafinil. J Neurosci 28:8462-8469. CrossRef Medline

Sapin E, Lapray D, Bérod A, Goutagny R, Léger L, Ravassard P, Clément O, Hanriot L, Fort P, Luppi PH (2009) Localization of the brainstem GABAergic neurons controlling paradoxical (REM) sleep. PLoS One 4:e4272. CrossRef Medline

Sherin JE, Shiromani PJ, McCarley RW, Saper CB (1996) Activation of ventrolateral preoptic neurons during sleep. Science 271:216-219. CrossRef Medline

Siegel JM (2009) Sleep viewed as a state of adaptive inactivity. Nat Rev Neurosci 10:747-753. CrossRef Medline

Taylor NE, Van Dort CJ, Kenny JD, Pei J, Guidera JA, Vlasov KY, Lee JT, Boyden ES, Brown EN, Solt K (2016) Optogenetic activation of dopamine neurons in the ventral tegmental area induces reanimation from general anesthesia. Proc Natl Acad Sci U S A 113:12826-12831. CrossRef Medline

Taylor SR, Badurek S, Dileone RJ, Nashmi R, Minichiello L, Picciotto MR 
(2014) GABAergic and glutamatergic efferents of the mouse ventral tegmental area. J Comp Neurol 522:3308-3334. CrossRef Medline

Trampus M, Ongini E (1990) The D1 dopamine receptor antagonist SCH 23390 enhances REM sleep in the rat. Neuropharmacology 29:889-893. CrossRef Medline

Trampus M, Ferri N, Monopoli A, Ongini E (1991) The dopamine D1 receptor is involved in the regulation of REM sleep in the rat. Eur J Pharmacol 194:189-194. CrossRef Medline

Trampus M, Ferri N, Adami M, Ongini E (1993) The dopamine D1 receptor agonists, A68930 and SKF 38393, induce arousal and suppress REM sleep in the rat. Eur J Pharmacol 235:83-87. CrossRef Medline

Unno K, Ozaki T, Mohammad S, Tsuno S, Ikeda-Sagara M, Honda K, Ikeda
M (2012) First and second generation $\mathrm{H}(1)$ histamine receptor antagonists produce different sleep-inducing profiles in rats. Eur J Pharmacol 683:179-185. CrossRef Medline

Urban DJ, Roth BL (2015) DREADDs (designer receptors exclusively activated by designer drugs): chemogenetic tools with therapeutic utility. Annu Rev Pharmacol Toxicol 55:399-417. CrossRef Medline

Vong L, Ye C, Yang Z, Choi B, Chua S Jr, Lowell BB (2011) Leptin action on GABAergic neurons prevents obesity and reduces inhibitory tone to POMC neurons. Neuron 71:142-154. CrossRef Medline

Wisor JP, Nishino S, Sora I, Uhl GH, Mignot E, Edgar DM (2001) Dopaminergic role in stimulant-induced wakefulness. J Neurosci 21:1787-1794. CrossRef Medline 